\title{
Occurrence of benthic microbial nitrogen fixation coupled to sulfate reduction in the seasonally hypoxic Eckernförde Bay, Baltic Sea
}

\author{
V. J. Bertics ${ }^{1, *}$, C. R. Löscher ${ }^{2}$, I. Salonen ${ }^{2}$, A. W. Dale ${ }^{1}$, J. Gier ${ }^{1}$, R. A. Schmitz ${ }^{2}$, and T. Treude ${ }^{1}$ \\ ${ }^{1}$ GEOMAR, Helmholtz Centre for Ocean Research Kiel, Wischhofstrasse 1-3, 24148 Kiel, Germany \\ ${ }^{2}$ Institut für Allgemeine Mikrobiologie, Christian-Albrechts-Universität Kiel, Am Botanischen Garten 1-9, \\ 24118 Kiel, Germany \\ * present address: Harvard University, Biological Laboratories, Room 3085, 16 Divinity Avenue, Cambridge, MA 02138, USA
}

Correspondence to: V. J. Bertics (vbertics@fas.harvard.edu), T. Treude (ttreude@geomar.de)

Received: 7 May 2012 - Published in Biogeosciences Discuss.: 6 June 2012

Revised: 24 January 2013 - Accepted: 2 February 2013 - Published: 1 March 2013

\begin{abstract}
Despite the worldwide occurrence of marine hypoxic regions, benthic nitrogen $(\mathrm{N})$ cycling within these areas is poorly understood and it is generally assumed that these areas represent zones of intense fixed $\mathrm{N}$ loss from the marine system. Sulfate reduction can be an important process for organic matter degradation in sediments beneath hypoxic waters and many sulfate-reducing bacteria (SRB) have the genetic potential to fix molecular $\mathrm{N}\left(\mathrm{N}_{2}\right)$. Therefore, SRB may supply fixed $\mathrm{N}$ to these systems, countering some of the $\mathrm{N}$ lost via microbial processes, such as denitrification and anaerobic ammonium oxidation. The objective of this study was to evaluate if $\mathrm{N}_{2}$ fixation, possibly by $\mathrm{SRB}$, plays a role in $\mathrm{N}$ cycling within the seasonally hypoxic sediments from the Eckernförde Bay, Baltic Sea. Monthly samplings were performed over the course of one year to measure nitrogenase activity (NA) and sulfate reduction rates, to determine the seasonal variations in bioturbation (bioirrigation) activity and important benthic geochemical profiles, such as sulfur and $\mathrm{N}$ compounds, and to monitor changes in water column temperature and oxygen concentrations. Additionally, at several time points, the active $\mathrm{N}$-fixing community was examined via molecular tools. Integrated rates of $\mathrm{N}_{2}$ fixation (approximated from NA) and sulfate reduction showed a similar seasonality pattern, with highest rates occurring in August (approx. 22 and $880 \mathrm{nmol} \mathrm{cm}^{-3} \mathrm{~d}^{-1}$ of $\mathrm{N}$ and $\mathrm{SO}_{4}^{2-}$, respectively) and October (approx. 22 and $1300 \mathrm{nmol} \mathrm{cm}^{-3} \mathrm{~d}^{-1}$ of $\mathrm{N}$ and $\mathrm{SO}_{4}^{2-}$, respectively), and lowest rates occurring in February (approx. 8 and $32 \mathrm{nmol} \mathrm{cm}^{-3} \mathrm{~d}^{-1}$ of $\mathrm{N}$ and $\mathrm{SO}_{4}^{2-}$, respectively). These rate changes were positively correlated with bottom water temperatures and previous reported plank-
\end{abstract}

ton bloom activities, and negatively correlated with bottom water oxygen concentrations. Other variables that also appeared to play a role in rate determination were bioturbation, bubble irrigation and winter storm events. Molecular analysis demonstrated the presence of nifH sequences related to two known $\mathrm{N}_{2}$ fixing SRB, namely Desulfovibrio vulgaris and Desulfonema limicola, supporting the hypothesis that some of the nitrogenase activity detected may be attributed to SRB. Overall, our data show that Eckernförde Bay represents a complex ecosystem where numerous environmental variables combine to influence benthic microbial activities involving $\mathrm{N}$ and sulfur cycling.

\section{Introduction}

Dissolved oxygen in the world ocean is a key factor driving marine biogeochemical processes and nutrient turnover, especially in regards to the marine nitrogen $(\mathrm{N})$ and carbon cycles (Helly and Levin, 2004; Bange et al., 2005; Middelburg and Levin, 2009). When substantial organic carbon is available, oxygen demands become higher, and when combined with sluggish or restricted water circulation, oxygen minimum zones (areas with dissolved oxygen $<22 \mu \mathrm{M}$ ) can develop in large midwater regions, typically between 200-1000 m water depth (Wyrtki, 1962; Kamykowski and Zentara, 1990; Levin, 2003). The same process can lead to hypoxia (dissolved oxygen $<63 \mu \mathrm{M}$ ) in silled basins, fjords and enclosed seas (e.g. Black Sea, Cariaco Basin, Koljø Fjord; Anderson and Devol, 1987; Middelburg et al., 1991; 
Rosenberg et al., 2001). It is estimated that the benthic area of sediments subjected to hypoxia world-wide is over $10^{6} \mathrm{~km}^{2}$ (Helly and Levin, 2004). Due to global warming induced changes in the marine environments, as well as human alterations of coastal ecosystems, these oxygen minimum zones and hypoxic regions are expanding and are predicted to continue to do so for the near future (Stramma et al., 2008; Middelburg and Levin, 2009).

$\mathrm{N}$-cycling within oxygen-depleted regions is still poorly understood and therefore has become a topic of much debate. Until recently it was assumed that the dominant process involved in $\mathrm{N}$-loss in these areas was denitrification (Ulloa and Pantoja, 2009), a process that uses nitrate as an electron acceptor for organic matter degradation. In recent years, it has been shown that anaerobic ammonium oxidation (anammox) with nitrite, sometimes possibly linked to dissimilatory nitrate reduction (Kartal et al., 2007), can also play an important role (Dalsgaard et al., 2005; Kuypers et al., 2005; Thamdrup et al., 2006; Hamersley et al., 2007). Additionally, despite the fact that oxygen concentrations are so low, Molina and Farías (2009) have shown that significant rates of nitrification can also be observed, even at oxygen concentrations $\leq 5 \mu \mathrm{M}$. However, all of these processes may lead to a loss of oceanic fixed $\mathrm{N}$, mostly through the eventual production of molecular nitrogen $\left(\mathrm{N}_{2}\right)$ and are therefore categorized as a sink for fixed $\mathrm{N}$.

Globally, several estimates of marine fixed $\mathrm{N}$ sinks greatly exceed estimates of marine fixed $\mathrm{N}$ sources, with some estimates suggesting a deficit as great as $\sim 200 \mathrm{Tg} \mathrm{N} \mathrm{yr}^{-1}$ (Codispoti et al., 2001; Brandes and Devol, 2002; Hulth et al., 2005; Codispoti, 2007). These results would indicate that either the ocean is decreasing in biologically available $\mathrm{N}$ over time, which geochemical data suggest is not the case (Deutsch et al., 2004), or an incorrect estimate of sources and sinks (Capone and Knapp, 2007). Because biological $\mathrm{N}_{2}$ fixation is the primary input of fixed $\mathrm{N}$ into the marine biosphere and because biologically available $\mathrm{N}$ is often limiting for marine productivity (Thomas, 1966; Carpenter and Capone, 2008; Moisander et al., 2012), the microbial process of $\mathrm{N}_{2}$ fixation has traditionally received much attention. While the majority of studies concerning marine $\mathrm{N}_{2}$ fixation has focused on the water column, many benthic habitats also have been examined, such as coral reefs, photosynthetic microbial mats, mangrove sediments, and seagrass rhizospheres (Capone, 1983, 1988; Carpenter and Capone, 2008) and more recently, shallow estuarine and bioturbated sediments (e.g. Fulweiler et al., 2007; Bertics et al., 2010). However, the majority of benthic studies have focused on $\mathrm{N}_{2}$ fixation linked to phototrophic activity, and not on dark heterotrophic-driven $\mathrm{N}_{2}$ fixation. For both pelagic and benthic $\mathrm{N}_{2}$ fixation research, much of the current work is focusing on methodological refinements (e.g. underestimation of $\mathrm{N}_{2}$ fixation rates when using the bubble technique; Mohr et al., 2010; Großkopf et al., 2012) and exploring locations that were typically thought to be areas of fixed $\mathrm{N}$ loss, such as oxygen minimum zones and hypoxic regions, in the hope of resolving the global marine $\mathrm{N}$ budget discrepancy.

As mentioned earlier, oxygen-depleted waters typically form when there is high organic matter loading to the marine system. Much of this organic carbon reaches the sediment surface where it can promote high rates of microbial activity, such as increased sulfate reduction. Because many sulfate-reducing bacteria (SRB) have the genetic potential to fix N (Zehr et al., 1995) and have been shown to do so in a variety of benthic habitats (e.g. Nielsen et al., 2001; Steppe and Paerl, 2002; Bertics et al., 2010) it is possible that these organisms could facilitate the biological fixation of $\mathrm{N}_{2}$ in sediments beneath hypoxic waters. To test this hypothesis, a region of the German Baltic Sea, Eckernförde Bay, known to undergo seasonal hypoxia in late spring through early autumn caused by strong water stratification (Orsi et al., 1996b; Hansen et al., 1999; Bange et al., 2011), and known to support seasonal variations in microbial sulfate reduction (Treude et al., 2005), was selected for an intense year-long study. Over the course of the year, water column oxygen concentrations, salinity, density, and temperature were monitored and benthic microbial rates of $\mathrm{N}_{2}$ fixation (based on nitrogenase activity) and sulfate reduction, along with porewater geochemistry, were determined monthly. Additionally, at several selected time points, molecular analysis of key functional genes was performed for determination of which microorganisms were present with the genetic potential of performing $\mathrm{N}_{2}$ fixation. The overall goal was to determine whether $\mathrm{N}_{2}$ fixation, especially dark heterotrophic $\mathrm{N}_{2}$ fixation, is occurring in Eckernförde Bay sediments, and if so, whether this activity (1) shows seasonal variability, and (2) is coupled to sulfate reduction.

\section{Materials and methods}

\subsection{Study site}

Eckernförde Bay, Germany $\left(54^{\circ} 31.15 \mathrm{~N}, 10^{\circ} 02.18 \mathrm{E}\right)$ is a semi-enclosed bay with a mean water depth of $\sim 28 \mathrm{~m}$, located in the southwestern Baltic Sea. Because of the shallow water depth, there is a strong benthic-pelagic coupling that results in organic-rich sediments (Orsi et al., 1996b) where the bulk of organic matter originates from plankton and macroalgal sources (Balzer et al., 1987). The presence of two water masses (salty North Sea and brackish Baltic Sea water), along with high surface water temperatures, causes strong stratification during the summer months. Consequently, mixing in the water column is reduced, strengthening the formation of a deep halocline (Hansen et al., 1999). During late summer, organic matter degradation coupled to phytoplankton blooms frequently cause oxygen deficiency in the isolated bottom water (Graf et al., 1983; Meyer-Reil, 1983; Hansen et al., 1999). In late autumn and winter, storms and decreased surface water temperatures cause a breakdown 
in this stratification and an increase in nutrient and oxygen concentrations in deeper waters (Hansen et al., 1999). For more information on Eckernförde Bay, see Orsi et al. (1996b) and Treude et al. (2005).

\subsection{Water column and sediment sampling}

From April 2010 to February 2011, field sampling was conducted monthly, with the exceptions that June and July sampling was done from 30 June-2 July (this sampling will hereafter be termed June/July) and that January sampling did not occur due to bad weather. All field sampling was conducted onboard the R/V Alkor, the RC Littorina, or the RB Polarfuchs. At each sampling time, an initial cast of a 6bottle rosette with attached CTD (Hydro-Bios, Kiel, Germany) was performed to profile water column temperature, salinity, and oxygen concentrations (based on optode measurements). Profiles were saved and viewed on a PC using the OceanLab 3 software (Hydro-Bios). Following the cast, a miniature multiple corer (MUC; K. U. M., Kiel, Germany) equipped with four cores liners (length $\sim 60 \mathrm{~cm}$, inner diameter $10 \mathrm{~cm}$ ) was used to obtain altogether 6-12 sediment cores of $\sim 35 \mathrm{~cm}$ length. Cores were then brought back to GEOMAR and taken to a $10^{\circ} \mathrm{C}$ cold room where the cores were processed within a few hours of collection.

\subsection{Porewater geochemistry and sediment properties}

Porewater samples were collected each month from two MUC cores. One core was sampled using anaerobic (i.e. flushed with $\mathrm{N}_{2}$ gas) Rhizons (Rhizosphere Research Comp., Wageningen, the Netherlands) and the other core was sampled using a low pressure (1-5 bar argon) porewater press containing $0.2 \mu \mathrm{m}$ cellulose acetate Nuclepore ${ }^{\circledR}$ filters. Cores were sampled in $1-\mathrm{cm}$ intervals to a depth of $10 \mathrm{~cm}$, below which $3-\mathrm{cm}$ intervals were used. Porewater collected via Rhizons was immediately analyzed for ammonium concentrations and porewater collected via the press was immediately analyzed for sulfate concentrations. Ammonium measurements were performed on a Hitachi UV/VIS spectrophotometer following standard photometric procedures with a precision of $5.5 \%$ (Grasshoff et al., 1999). Because high sulfide concentrations may interfere with ammonium measurements, these sub-samples were acidified with $20 \mu \mathrm{L}$ of $\mathrm{HCl}$ and bubbled with argon to strip any hydrogen sulfide. Sulfate concentrations were measured using ion chromatography with the IAPSO seawater standard for calibration (precision of $1.5 \%$ ). For these measurements, a Metrohm ion-chromatograph equipped with a conventional anion-exchange column, using carbonate-bicarbonate solution as an eluent, and a conductivity detector was used. Wet sediment samples were collected for determination of porosity. Porosity was calculated from the water content (weighing fresh and freeze-dried sediment samples) assuming a dry solid density of $2.65 \mathrm{~g} \mathrm{~cm}^{-3}$.
Additionally, as an indication of seasonal benthic bioturbation activity, we present the results from bioirrigation experiments performed on MUC cores obtained, in the same manner as was previously described, on 12 occasions between February and December 2010 by Dale et al. (2013). In short, $\mathrm{Br}^{-}$was added in large excess to the water overlying the sediment to act as a dissolved conservative tracer. Cores were incubated for a known period of time and $\mathrm{Br}^{-}$was determined in the squeezed porewater by ion chromatography using a Metrohm ion chromatograph with a conventional anion exchange column with IAPSO seawater standard for calibration (relative precision of $<2 \%$ for natural seawater samples). The determination of the depth distribution of $\mathrm{Br}^{-}$allowed for the estimation of irrigation rates by modeling the transient infiltration of $\mathrm{Br}^{-}$into the sediment. For more details on this method and for further explanation concerning the calculation of the porewater-derived bioirrigation coefficient $\alpha$, see Dale et al. (2013).

\subsection{Benthic nitrogenase activity (NA)}

From each sampling month, one MUC core was sliced using the following sampling scheme: $0-10 \mathrm{~cm}$ sediment depth in 1-cm intervals, $10-20 \mathrm{~cm}$ sediment depth in $2-\mathrm{cm}$ intervals, and $20-25 \mathrm{~cm}$ sediment depth in one $5-\mathrm{cm}$ interval (due to core length, June/July sampling went to $20 \mathrm{~cm}$ and $\mathrm{Au}-$ gust sampling went to $18 \mathrm{~cm}$ ). All samples were then analyzed for nitrogenase activity (NA) using the acetylene reduction assay (Capone, 1993). In this study, triplicate 10$\mathrm{cm}^{3}$ sediment samples from each depth horizon were placed in $60 \mathrm{~mL}$ serum vials flushed with $\mathrm{N}_{2}$. Each vial was crimp sealed, injected with $5 \mathrm{~mL}$ of $\mathrm{C}_{2} \mathrm{H}_{2}$ to saturate the nitrogenase, if present, and the increase in $\mathrm{C}_{2} \mathrm{H}_{4}$ was assayed over a week (total of 5 time points, including a time-zero) on a gas chromatograph (GC) with a flame ionization detector. At each time point, the headspace of each vial was sampled and directly injected into the GC. Incubations were kept in the dark and at in situ temperature $\left(3-13{ }^{\circ} \mathrm{C}\right.$ based on CTD data) based on the bottom water temperature results from the CTD casts. $\mathrm{N}_{2}$ fixation rates were calculated from the linear portion of the NA results using a conversion factor of $3 \mathrm{C}_{2} \mathrm{H}_{4}: 1 \mathrm{~N}_{2}$, which is based on previous direct ${ }^{15} \mathrm{~N}_{2}$ comparisons in seagrass habitats (Patriquin and Knowles, 1972; O'Donohue et al., 1991) and with the marine cyanobacteria Trichodesmium (Orcutt et al., 2001; Capone et al., 2005), and additionally has been used in other coastal sediments (e.g. Welsh et al., 1996).

In April and May, 2 sets of triplicate $5-\mathrm{cm}^{3}$ samples from each depth interval were placed into $15 \mathrm{~mL}$ serum vials flushed with $\mathrm{N}_{2}$ and used as control samples. To one vial set, no $\mathrm{C}_{2} \mathrm{H}_{2}$ was added to determine if natural $\mathrm{C}_{2} \mathrm{H}_{4}$ production was occurring and to the other set, $1 \mathrm{~mL}$ of $37.5 \%$ Formalin was added along with $1 \mathrm{~mL}$ of $\mathrm{C}_{2} \mathrm{H}_{2}$ to serve as a kill control. No increase in $\mathrm{C}_{2} \mathrm{H}_{4}$ was detected in these control samples. 


\subsection{Benthic sulfate reduction rates}

During each sampling month, 2 MUC cores were subsampled with smaller core liners (length $30 \mathrm{~cm}$, inner diameter $2.6 \mathrm{~cm}$ ) for the determination of sulfate reduction rates through whole-core incubation experiments (Jørgensen, 1978) using the radioactive tracer ${ }^{35} \mathrm{SO}_{4}^{2-}$. In total, there were 4 small cores used for sulfate reduction measurements (3 experimental and 1 control). Each experimental core was injected with ${ }^{35} \mathrm{SO}_{4}^{2-}(6 \mu \mathrm{L}, 200 \mathrm{kBq}$, specific activity $37 \mathrm{TBq} \mathrm{mmol}{ }^{-1}$ ) at $1-\mathrm{cm}$ depth intervals throughout the length of the sediment core (length $20-25 \mathrm{~cm}$ ) and incubated at in situ bottom-water temperatures $\left(3-13{ }^{\circ} \mathrm{C}\right.$ based on CTD data) for $18-24 \mathrm{~h}$ in the dark. After incubation, cores were sliced in $1-\mathrm{cm}$ increments and each sub-sample $\left(\sim 5 \mathrm{~cm}^{-3}\right)$ was transferred to $20 \mathrm{~mL}$ zinc acetate $(20 \%$ $w / w)$. Controls were first transferred to zinc acetate before radiotracer addition. Sulfate reduction rates were determined using the method of Fossing and Jørgensen (1989) modified to a cold chromium distillation procedure after Kallmeyer et al. (2004).

\subsection{Amplification, cloning and sequencing of benthic nifH}

DNA was extracted from $\sim 100 \mathrm{mg}$ of sediment, collected in September 2010, using the FastDNA ${ }^{\circledR}$ SPIN Kit for Soil (Qbiogene Inc., Carlsbad, CA, USA). The nifH gene (encoding for one subunit of nitrogenase, the key enzyme of $\mathrm{N}_{2}$ fixation) was PCR amplified using primers and PCR conditions according to Zehr et al. (1998). Cloning of PCR amplicons was performed using the TopoTA Cloning ${ }^{\circledR}$ Kit (Invitrogen, Carlsbad, CA) following the manufacturer's instructions. Sanger sequencing (74 nifH sequences) was carried out by the Institute of Clinical Molecular Biology, Kiel, Germany. Sequences were phylogenetically analyzed using the ARB software package (Ludwig et al., 2004) on a $321 \mathrm{bp}$ fragment for $n i f H$, sequence differences were set on a minimum of $5 \%$.

\subsection{Temperature experiment}

To examine the effects of temperature on NA and sulfate reduction, an additional sampling of Eckernförde Bay was performed on 4 October 2011. As before, an initial CTD cast was used to determine bottom water temperature $\left(13^{\circ} \mathrm{C}\right)$. Following the CTD, 5 MUC cores ( 2 for NA, 2 for sulfate reduction, and 1 for porewater) were collected and brought back to a $10^{\circ} \mathrm{C}$ cold room at GEOMAR for processing within a few hours of collection. All cores were sub-sampled in the manner previously described, with the exception that sampling only reached a sediment depth of $16 \mathrm{~cm}$ and porewater was collected only via Rhizons.

For NA measurements, 2 sets of triplicate $12-\mathrm{cm}^{3}$ sediment samples from each depth horizon were placed in
$120 \mathrm{~mL}$ serum vials flushed with $\mathrm{N}_{2}$ and analyzed in the manner described above. Incubations were kept in the dark and one set of vials was kept at the lowest in situ temperature seen in Eckernförde Bay during our study $\left(3^{\circ} \mathrm{C}\right.$; February, 2011), while the other set was kept at the highest temperature $\left(13^{\circ} \mathrm{C}\right.$; October, 2011$)$.

For sulfate reduction rate measurements, 2 sets of triplicate sub-cores and one control sub-core were collected and assayed in the same manner as was described earlier. Identical to the NA incubations, one set of sub-cores was kept at $3^{\circ} \mathrm{C}$ while the other set was kept at $13^{\circ} \mathrm{C}$.

\section{Results}

\subsection{Water column parameters}

Over the course of the year, water column temperature, oxygen, and salinity varied greatly between months and with water depth (Fig. 1). Warmer waters $\left(>10^{\circ} \mathrm{C}\right)$ developed in the upper water column in May, reaching highest values $\left(>19^{\circ} \mathrm{C}\right)$ in August. In October, the entire water column was $>10^{\circ} \mathrm{C}$, but by November, temperatures began to decrease, reaching lowest values $\left(1-3^{\circ} \mathrm{C}\right)$ in February. In contrast, water column oxygen concentrations were highest $(>360 \mu \mathrm{M})$ in February. Hypoxic waters $(<63 \mu \mathrm{M})$ formed in the deeper water depths of August and persisted through October, reaching lowest values $(\sim 5 \mu \mathrm{M})$ in September. Bottom water salinity ranged from $19-24 \%$, while surficial water salinity ranged from $12-19 \%$. The smallest depth variation in salinity was seen in December (surficial 17\%o-bottom 19\%o), indicating water column mixing, most likely due to winter storm events and decreased surface water temperatures. The largest depth variation was seen in August (surficial 12\%o-bottom 24\%o), supporting the idea of summer stratification, which was also seen with water column temperatures and oxygen concentrations (Fig. 1).

\subsection{Sediment parameters}

Sediment porosity remained relatively stable over the course of the year. Typically, surface sediments had a porosity of $\sim 0.92$. Porosity then gradually decreased with sediment depth, reaching a porosity of $\sim 0.80$ at $25 \mathrm{~cm}$ sediment depth.

Bioirrigation was already detectable in cores collected in early February (2010) and reached a maximum coefficient value $\left(\alpha=0.38 \mathrm{~d}^{-1}\right)$ in late March (Fig. 2; Dale et al., 2013). Bioirrigation decreased after this time, eventually becoming almost undetectable starting in September $\left(\alpha<0.01 \mathrm{~d}^{-1}\right)$ and continuing like this through December. At the same time that bioirrigation became almost undetectable in September, bottom water oxygen concentrations reached their lowest values $(<5 \mu \mathrm{M}$, Fig. 1$)$. 

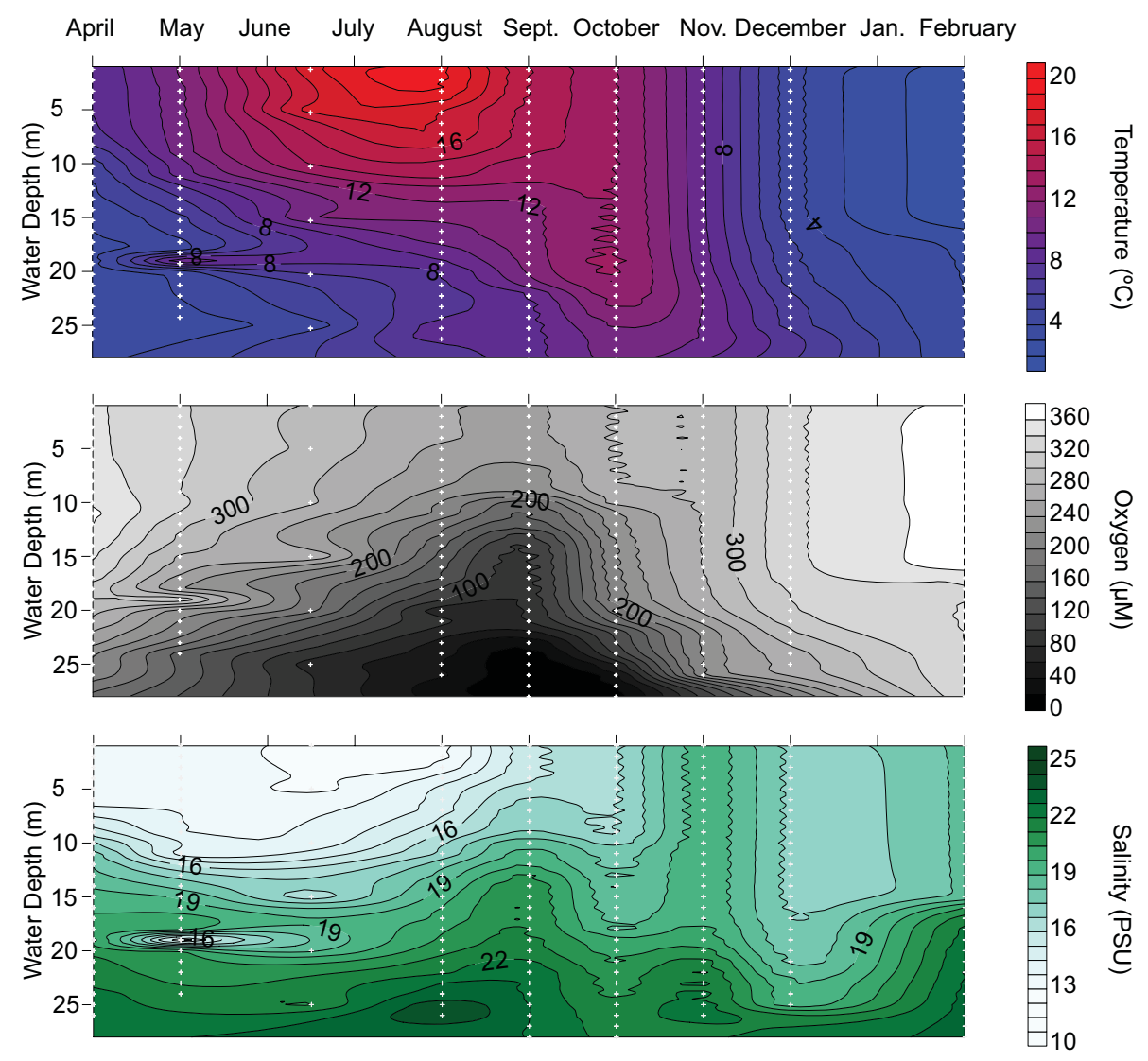

Fig. 1. Contour plots of water column temperature (upper), oxygen concentrations (middle), and salinity (lower) over the course of the study, from April 2010 to February 2011. White dots represent data collection points.

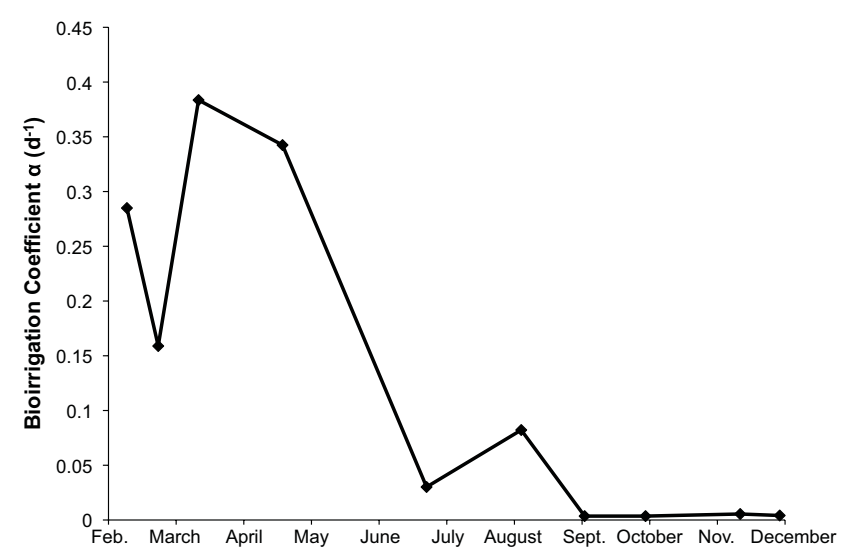

Fig. 2. Bioirrigation coefficients $(\alpha)$ for sediment cores collected from February through December 2010, as determined by Dale et al. (2013).

\subsection{Benthic biogeochemical rates and geochemistry}

Benthic nitrogenase activity (NA) closely mirrored sulfate reduction rates monthly and with depth in the sediment (Fig. 3). In general, sulfate reduction rates and NA were highest in the top $10 \mathrm{~cm}$ of the sediment throughout the year. For both microbial activities, highest rates were seen in the top $5 \mathrm{~cm}$ of the sediment in October, reaching a sulfate reduction rate of $190 \pm 44 \mathrm{nmol} \mathrm{SO}_{4}^{2-} \mathrm{cm}^{-3} \mathrm{~d}^{-1}$ at $0-1 \mathrm{~cm}$ sediment depth and a NA of $3.8 \pm 2.5 \mathrm{nmol} \mathrm{C}_{2} \mathrm{H}_{4} \mathrm{~cm}^{-3} \mathrm{~d}^{-1}$ at $1-2 \mathrm{~cm}$ sediment depth. In contrast, lowest rates were seen in the bottom $10 \mathrm{~cm}$ of sediment in February, dropping to immeasurable sulfate reduction rates for most sediment depths and a NA of $0.02 \pm 0.01 \mathrm{nmol} \mathrm{C}_{2} \mathrm{H}_{4} \mathrm{~cm}^{-3} \mathrm{~d}^{-1}$ in the $20-25 \mathrm{~cm}$ sediment depth interval. In May, a co-occurring peak of sulfate reduction and NA appeared in the $20-25 \mathrm{~cm}$ sediment depth interval, with a sulfate reduction rate of $49 \pm 7 \mathrm{nmol} \mathrm{SO}_{4}^{2-} \mathrm{cm}^{-3} \mathrm{~d}^{-1}$ and a NA of $2.4 \pm 1.6 \mathrm{nmol} \mathrm{C}_{2} \mathrm{H}_{4} \mathrm{~cm}^{-3} \mathrm{~d}^{-1}$. Integrating these microbial activities each month down to a sediment depth of $18 \mathrm{~cm}$ (Fig. 7), sulfate reduction rates ranged from $32.4 \mathrm{nmol} \mathrm{SO}{ }_{4}^{2-} \mathrm{cm}^{-2} \mathrm{~d}^{-1}$ (February) to $1301.2 \pm 146.3 \mathrm{nmol} \mathrm{SO} \mathrm{SO}_{4}^{2-} \mathrm{cm}^{-2} \mathrm{~d}^{-1}$ (October) and NA ranged from $7.6 \pm 0.4 \mathrm{nmol} \mathrm{N} \mathrm{cm}^{-2} \mathrm{~d}^{-1}$ (February) to $22.1 \pm 0.5 \mathrm{~N}_{2} \mathrm{~cm}^{-2} \mathrm{~d}^{-1}$ (August).

In November and February, there were two replicates for sulfate reduction measurements that displayed unusually high rates, over 1000 and $5000 \mathrm{nmol} \mathrm{SO}_{4}^{2-} \mathrm{cm}^{-3} \mathrm{~d}^{-1}$, 

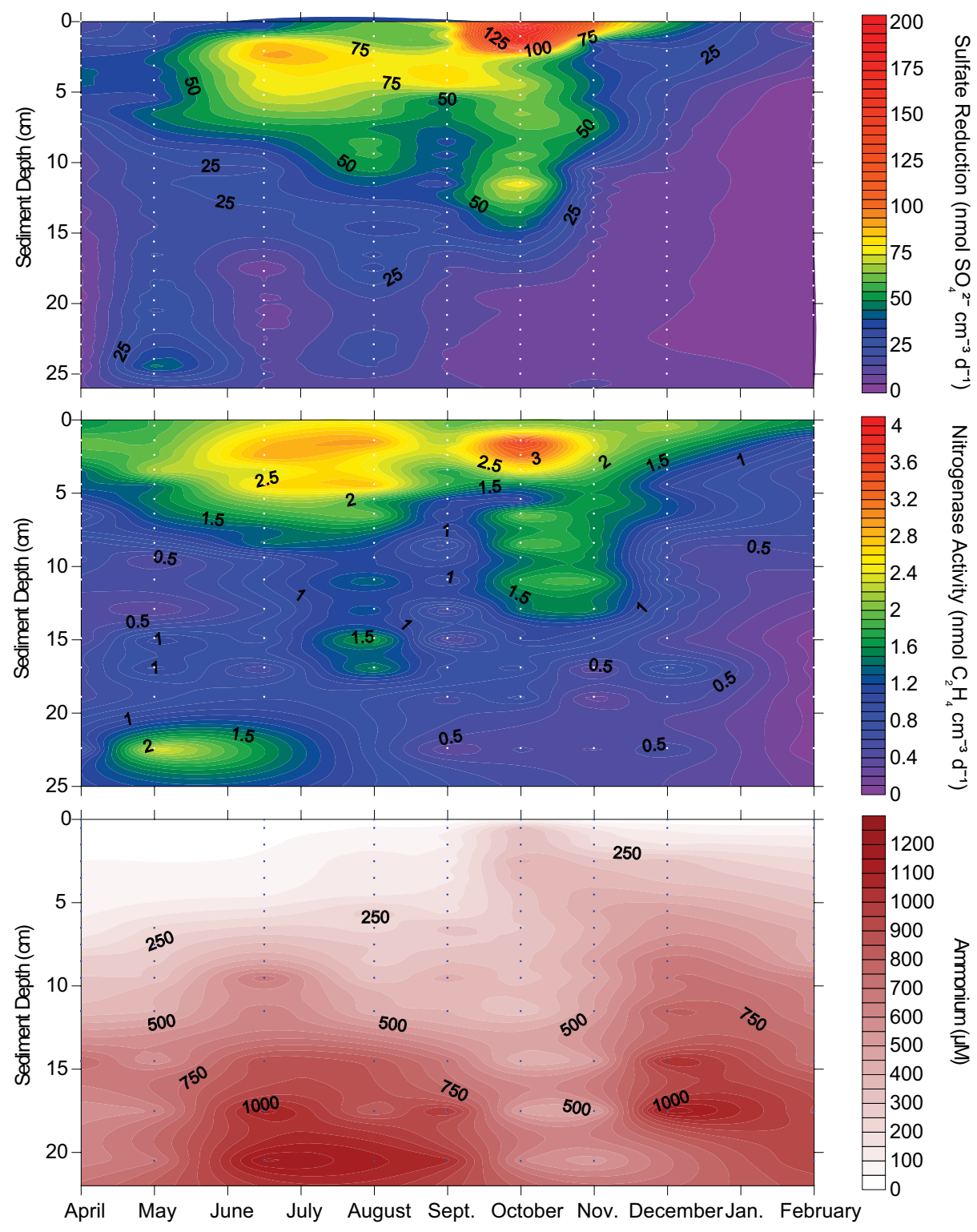

Fig. 3. Contour plots of benthic sulfate reduction rates (upper), nitrogenase activity (middle), and porewater ammonium concentrations (lower graph) over the course of the study, from April 2010 to February 2011. The white and blue dots represent data collection points. Note that the isoline scale on the sulfate reduction graph has been adjusted to allow higher resolution in the $0-100 \mathrm{nmol} \mathrm{SO}_{4}^{2-} \mathrm{cm}^{-3} \mathrm{~d}^{-1}$ range.

respectively, although all replicates in December displayed typical rates with depth (Fig. 4). Because these high rates appear to be rather localized, these were not used in formation of the sulfate reduction contour plot and integrated rates, but were instead plotted as individual profiles (Fig. 4). An explanation for these high rates is provided in the Discussion, Sect. 4.2.

Porewater ammonium concentrations (Fig. 3) generally showed an increase with depth in each month, with the exception of October and November, in which concentrations remained rather constant below $4 \mathrm{~cm}$ sediment depth. For the top $5 \mathrm{~cm}$ of sediment, the highest ammonium concentra- tions $(416 \mu \mathrm{M})$ were seen in October at a sediment depth of $2-3 \mathrm{~cm}$. For the $5-10 \mathrm{~cm}$ sediment depth horizon, the highest ammonium concentrations $(702 \mu \mathrm{M})$ were seen in December at a sediment depth of $9-10 \mathrm{~cm}$. For sediment depths greater than $10 \mathrm{~cm}$, the highest ammonium concentrations $(1214 \mu \mathrm{M})$ were seen in June/July in the very bottom of the core (19-22 cm). Overall, ammonium profiles tended to show the opposite trend when compared to the NA and sulfate reduction rate profiles, with months displaying high peaks in microbial activities also showing little variation in, and typically lower concentrations of, ammonium with sediment depth. 


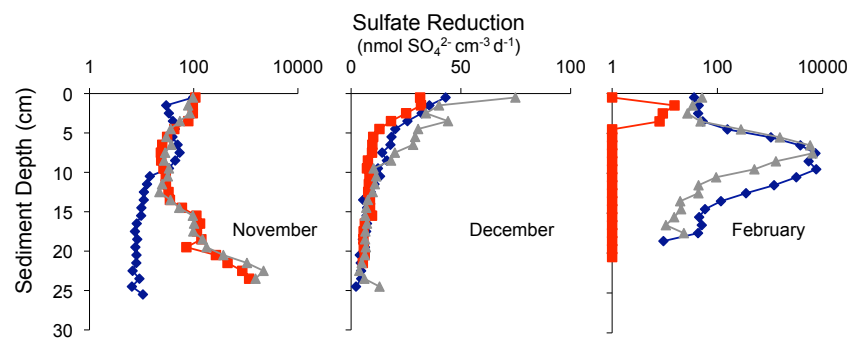

Fig. 4. Sulfate reduction depth profiles of the November 2010 and February 2011 sampling, which revealed exceptionally high rates in some replicates that were not included in contour plots (Fig. 3). Profiles from December 2010 are shown for comparison purposes. Each line (red, blue, and grey) represents a replicate sub-core used for the rate measurements. Please note the logarithmic scale for November and February.

\section{4 nifH gene analysis}

In general, the nifH gene sequences detected in September samples clustered with those from proteobacteria and those from Cluster III, as defined by Zehr and Turner (2001), while there were no cyanobacterial nifH gene sequences detected (Fig. 5). Two of the organisms that clustered with September nifH sequences were SRB, namely Desulfovibrio vulgaris (Postgate, 1984; Heidelberg et al., 2004) and Desulfonema limicola (Widdel, 1989; Fukui et al., 1999). Two of the other organisms, with which September nifH sequences clustered, belonged to genera with members capable of performing sulfur reduction, namely Acrobacter nitrofigilis and Sulfurospirillum multivorans (Madigan et al., 2003).

\subsection{Temperature experiment}

In general, sulfate reduction rates and NA were higher in October 2011 samples incubated at $13{ }^{\circ} \mathrm{C}$ versus $3{ }^{\circ} \mathrm{C}$ (Fig. 6). One exception was seen with the NA present in the $14-16 \mathrm{~cm}$ sediment depth horizon, where 2 out of 3 replicates incubated at $3{ }^{\circ} \mathrm{C}$ displayed higher NA than those incubated at $13{ }^{\circ} \mathrm{C}$. Integrating to $15 \mathrm{~cm}$ sediment depth, sulfate reduction rates for incubations at $13^{\circ} \mathrm{C}\left(1052 \mathrm{nmol} \mathrm{SO}_{4}^{2-} \mathrm{cm}^{-2} \mathrm{~d}^{-1}\right)$ were 5 times higher $\left(Q_{10}=5.2\right)$ than those at $3^{\circ} \mathrm{C}\left(203 \mathrm{nmol} \mathrm{SO}_{4}^{2-} \mathrm{cm}^{-2} \mathrm{~d}^{-1}\right)$. For NA, integrating to $16 \mathrm{~cm}$ sediment depth, incubations at $13^{\circ} \mathrm{C}\left(22 \mathrm{nmol} \mathrm{C}_{2} \mathrm{H}_{4} \mathrm{~cm}^{-2} \mathrm{~d}^{-1}\right)$ were 2 times higher $\left(Q_{10}=2\right)$ than those at $3{ }^{\circ} \mathrm{C}\left(11 \mathrm{nmol} \mathrm{C}_{2} \mathrm{H}_{4} \mathrm{~cm}^{-2} \mathrm{~d}^{-1}\right)$.

\section{Discussion}

\subsection{Benthic nitrogen fixation coupled to sulfate reduction}

Sulfate reduction is one of the most dominant biogeochemical processes in marine sediments, especially in coastal re- gions where sulfate reduction can account for $>50 \%$ of organic matter degradation (Jørgensen, 1977a, 1982; Canfield, 1989). In coastal hypoxic sediments, this estimate can be even higher, reaching $>75 \%$ of organic matter degradation (Rowe et al., 2002). Many sulfate-reducing bacteria (SRB) have the genetic potential to fix $\mathrm{N}_{2}$ (Zehr et al., 1995) and have long been shown to do so in both laboratory and environmental settings (e.g. Sisler and Zobell, 1951; Le Gall et al., 1959; Riederer-Henderson and Wilson, 1970; Postgate et al., 1985; Welsh et al., 1996; Bertics et al., 2010). Combining this ability with the high abundance of SRB in certain marine sediments, it has been suggested that SRB may play a significant role in supplying fixed $\mathrm{N}$ to benthic communities, in particular, those present in $\mathrm{N}$ deficient sediments (Herbert, 1975; Nedwell and Aziz, 1980; McGlathery et al., 1998).

In this study, sulfate reduction depth profiles correlated with depth profiles of NA for each sampling month, suggesting that these two processes may be linked in Eckernförde Bay sediments. Looking at the contour plots (Fig. 3), areas of increased sulfate reduction activity often displayed cooccurring increases in NA. Integrating these microbial activities down to a sediment depth of $18 \mathrm{~cm}$ (Fig. 7), both activities showed a similar seasonality trend, with highest integrated rates occurring during the summer and fall months (June/July-November) and lowest rates during the winter and spring months (December-May). Interestingly, the ratio between $\mathrm{N}_{2}$ fixation and sulfate reduction changes dramatically over the course of the year, signifying that different environmental factors may be impacting these rates. These factors will be discussed in more detail in the next section. However, the overall trend similarities again suggest that $\mathrm{N}_{2}$ fixation may be coupled to, or at least respond to, some of the same environmental factors as sulfate reduction. This idea was further supported by the results from the nifH gene analysis (Fig. 5), in which the majority of benthic Eckernförde Bay nifH sequences obtained in this study were related to two known $\mathrm{N}_{2}$ fixing SRB (Desulfovibrio vulgaris and Desulfonema limicola) or to organisms in the same genera with other SRB. Therefore, it is likely that much of the NA seen in Eckernförde Bay sediments is carried out by SRB.

Interestingly, Eckernförde Bay sediments are not generally thought to be deficient in reduced $\mathrm{N}$, having porewater ammonium concentrations as high as $1200 \mu \mathrm{M}$ (Fig. 3). Because ammonium is a known inhibitor of $\mathrm{N}_{2}$ fixation (Postgate 1982; Dixon, 1984) and is a source of fixed $\mathrm{N}$ to the microbial community, it is unclear why SRB would perform $\mathrm{N}_{2}$ fixation in these sediments. However, $\mathrm{N}_{2}$ fixation has been shown to remain apparently unaffected by substantial $(>100 \mu \mathrm{M})$ ammonium concentrations in many other benthic environments (for review of these studies see Knapp, 2012), suggesting that ammonium inhibition in sediments may be more complex than originally thought. These complexities are even more apparent when looking at the high rates of $\mathrm{N}_{2}$ fixation in dark, ammonium-rich sediments (e.g. Bertics et al., 2010). One possible explanation for $\mathrm{N}_{2}$ fixation in the 


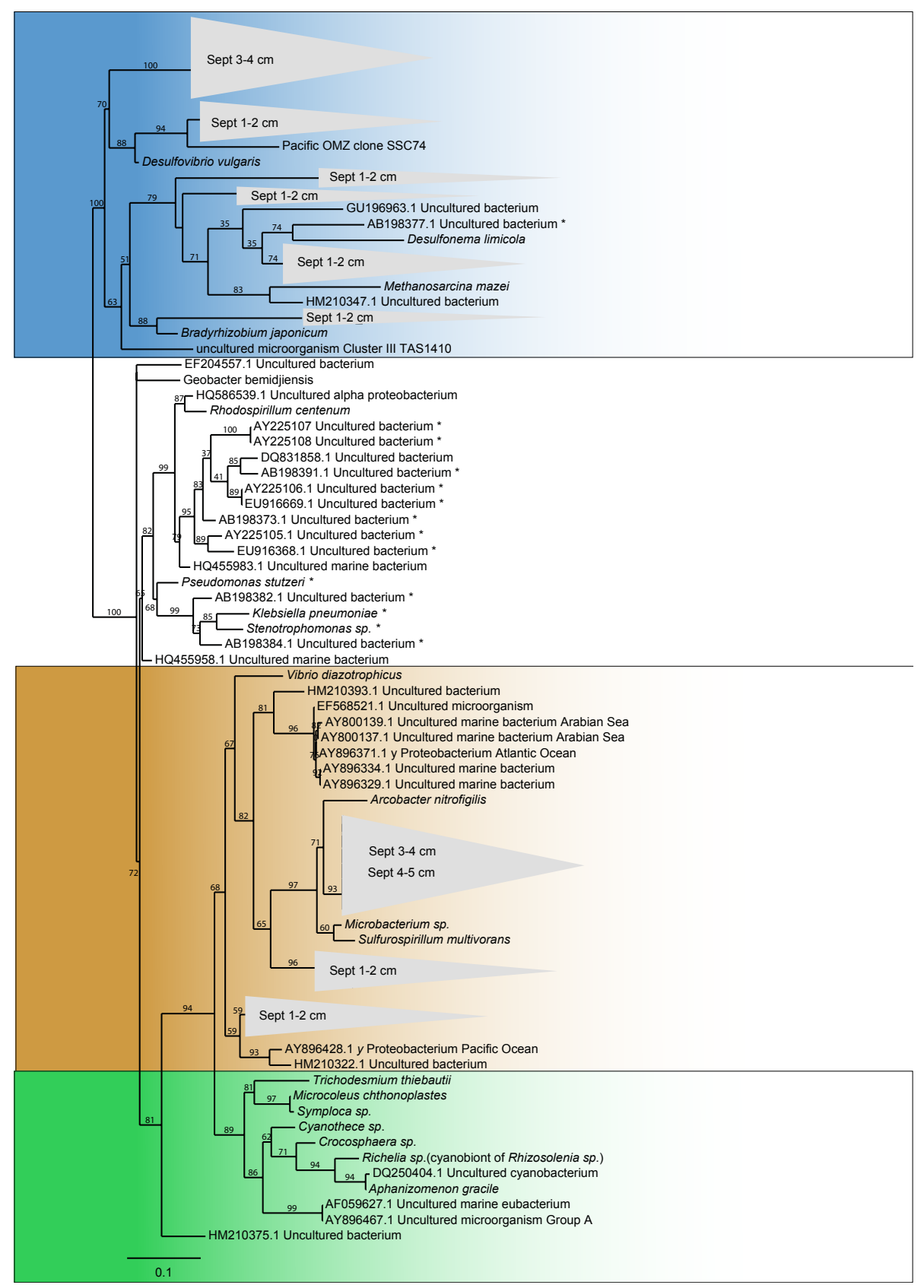

Fig. 5. Phylogenetic tree based on the analysis of 74 nifH gene sequences retrieved in this study. Novel identified clusters are indicated by grey triangles. Cyanobacterial reference sequences are highlighted in green, proteobacterial sequences are in brown, and Cluster III sequences as defined by Zehr and Turner (2001) in blue. Bootstrapped values (\%) above 50, out of 100, are shown on branches. The scale bar represents $10 \%$ estimated sequence divergence. Sequences marked with an asterisk indicate likely contaminated PCR products previously reported by Turk et al. (2011), the novel clusters are mostly distant from those sequences.

presence of high ammonium concentrations is that benthic $\mathrm{N}_{2}$ fixation may serve as an excess electron sink, especially if a viable Calvin-Benson-Bassham pathway is not present (Joshi and Tabita, 1996; Tichi and Tabita, 2000).

Overall, Eckernförde Bay NA was highest $\left(>2 \mathrm{nmol} \mathrm{C}_{2} \mathrm{H}_{4} \mathrm{~cm}^{-3} \mathrm{~d}^{-1}\right.$ ) when ammonium was $<400 \mu \mathrm{M}$. These results could suggest that perhaps there is some de- gree of $\mathrm{N}$ deficiency, possibly on the micro-scale level, which could be overlooked or lost when using traditional porewater extraction techniques that combine all porewater collected over a given depth interval. However, it should be noted that some of the ammonium variations seen between the different sampling months could be due to spatial variability, as only one core from each month 

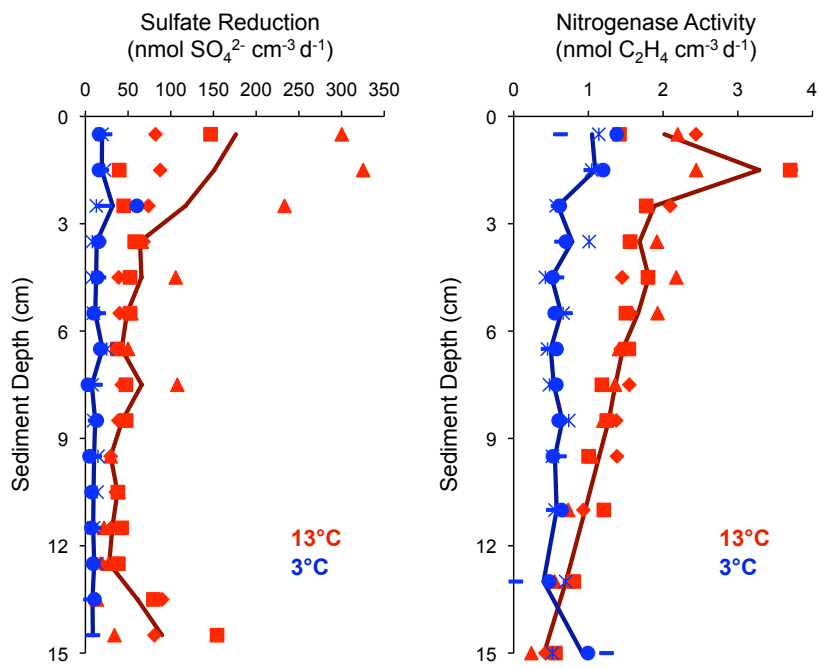

bial rates, a temperature experiment was performed and the results indicated that, in general, both sulfate reduction rates and NA increased when sediments were incubated at $13{ }^{\circ} \mathrm{C}$ versus $3{ }^{\circ} \mathrm{C}$ (Fig. 6). However, NA appeared to be less affected by temperature changes, having a $Q_{10}$ of 2 , versus a $Q_{10}$ of 5.2 for sulfate reduction rates, which is higher than the previous reported $Q_{10}$ of $3 \pm 0.5$ for sulfate reduction in Aarhus Bay sediments (Thamdrup et al., 1998). This same temperature pattern was seen during the monthly sampling (Fig. 7), where NA varied less drastically with changing temperature than sulfate reduction rates.

The effect of temperature on Eckernförde Bay NA and sulfate reduction was not surprising based on a previous study in Eckernförde Bay (Treude et al., 2005), which found that another microbial process, the anaerobic oxidation of methane (AOM), increased steadily from $4{ }^{\circ} \mathrm{C}$ to $20^{\circ} \mathrm{C}$, after which there was a small decline. This same study reported that

Fig. 6. Sulfate reduction (left) and nitrogenase activity (right) depth profiles obtained during the temperature experiment in October 2011. Results from the $3^{\circ} \mathrm{C}$ incubation are in blue, while results from the $13^{\circ} \mathrm{C}$ incubation are in red. Each replicate rate measurement is shown with a symbol and the average depth profile is indicated with a line.

was used for ammonium measurements. It is surprising to find that NA was still detectable when ammonium concentrations were $>1000 \mu \mathrm{M}$, ranging from $0.42 \pm 0.14$ to $0.98 \pm 0.24 \mathrm{nmol} \mathrm{C}_{2} \mathrm{H}_{4} \mathrm{~cm}^{-3} \mathrm{~d}^{-1}$. Based on several environmental studies it has been suggested that different benthic habitats will display differing levels of ammonium inhibition (Capone, 1988), with one study finding that a $50 \mathrm{mM}$ ammonium concentration was needed to inhibit $\mathrm{N}_{2}$ fixation in Spartina dominated sediments (Dicker and Smith, 1980). It is therefore uncertain if, and at which point, ammonium concentrations in Eckernförde Bay sediments would be high enough to completely inhibit benthic $\mathrm{N}_{2}$ fixation.

\subsection{Environmental controls on nitrogen fixation and Sulfate reduction in Eckernförde Bay Sediments}

\subsubsection{Temperature}

During spring and summer months, typically between March and September, the Eckernförde Bay water column becomes highly stratified (Graf et al., 1983; Orsi et al., 1996b; Bange et al., 2011), causing warmer waters at the surface and colder waters at depth (Fig. 1). In autumn months, when strong winds increase the water column mixing depth, warmer waters begin reaching the sediment surface (Graf et al., 1983; Orsi et al., 1996b). Benthic microbial activities (NA and sulfate reduction) positively correlated with bottom water temperatures over the year, with highest activities and temperatures occurring during the late summer/early autumn months (Fig. 7). To test whether temperature directly affected microAOM was higher in early September than in early March, which is in good agreement with the activity change along with temperature for the microbial processes observed in the present study. Additionally, it has been suggested that the warm productive autumn season leads to a shallowing of the Eckernförde Bay benthic AOM layer, which in turn leads to a shallowing of the methane-dependent sulfate reduction activity (Treude et al., 2005; Dale et al., 2013). This reasoning provides a possible explanation for the high sulfate reduction rates seen at the base of two replicate cores in November (Fig. 4). However, the observed peaks in sulfate reduction rates $\left(>2000 \mathrm{nmol} \mathrm{cm}^{-3} \mathrm{~d}^{-1}\right)$ greatly exceeded potential AOM rates reported from these depths at Boknis Eck ( $\sim 100 \mathrm{nmol} \mathrm{cm}^{-3} \mathrm{~d}^{-1}$, Treude et al., 2005), and we therefore suggest that they were likely caused by hot spots of labile organic matter rather than methane transport.

\subsubsection{Organic matter provided through pelagic production}

Heterotrophic microbial activity in sediments depends on organic matter availability, which can vary seasonally in most coastal marine environments, leading researchers to question if $\mathrm{N}_{2}$ fixation by SRB can vary seasonally as well (e.g. Welsh et al., 1996). Studies in the Kiel Bight (of which Eckernförde Bay is a fjord-like extension) have shown that the amount of organic material (from phytoplankton blooms, resuspension, and macrophyte debris) reaching the sediment varies drastically over the course of the year (Graf et al., 1983; Meyer-Reil, 1983). Increases in organic matter loading to the sediments led to increased microbial abundances and activity, as well as increased diversity and biomass of benthic macrofaunal communities. Focusing on Eckernförde Bay, a study looking at benthic microbial activities found that sulfate reduction rates were higher in early and late September than in early March and that these rates positively correlated with sedimentary chlorophyll $a$ concentrations, presumably coming from fresh algal material 


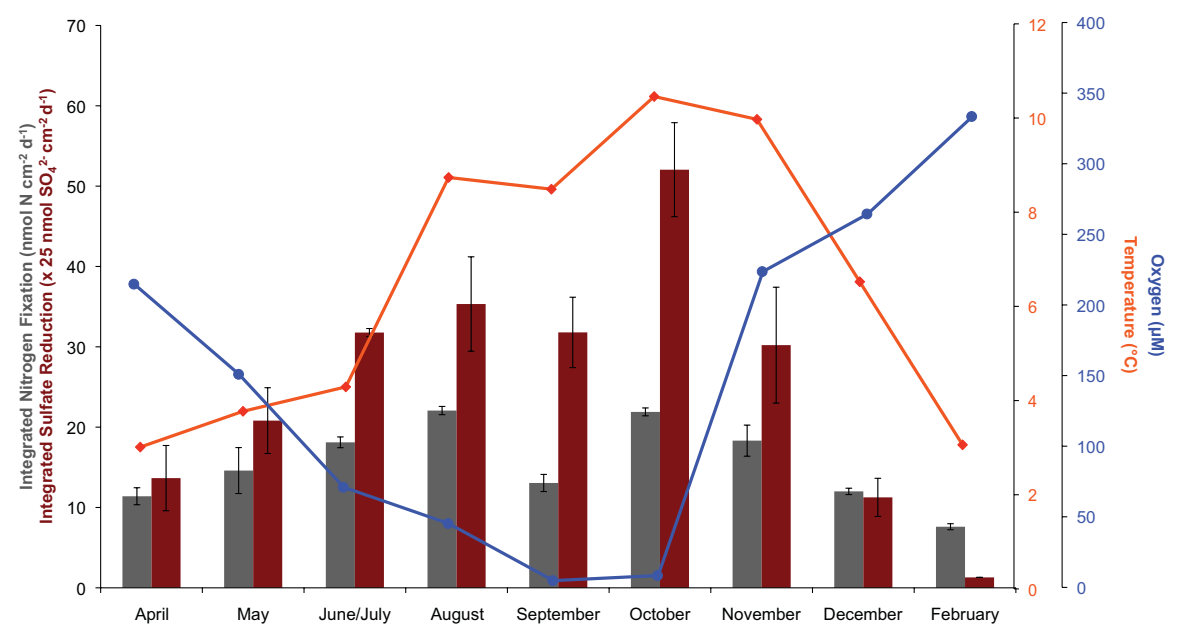

Fig. 7. Monthly integrated rates of sulfate reduction (red bars) and nitrogen fixation (grey bars) down to a sediment depth of $18 \mathrm{~cm}$ from April 2010 to February 2011. Overlaying this data are bottom water temperature (orange line) and oxygen concentrations (blue line). Error bars represent standard deviation.

being deposited on the sediment surface (Treude et al., 2005). Large phytoplanktonic blooms are known to occur in Eckernförde Bay in spring and autumn (Bange et al., 2011). From these blooms, $>50 \%$ (spring) and $>75 \%$ (autumn) of the material has been estimated to reach the benthic system via sedimentation (Smetacek et al., 1984), where it could then stimulate benthic microbial activity. Summer months (July/August) have been shown to support smaller phytoplanktonic blooms (Bange et al., 2011), of which $<25 \%$ is estimated to reach the sediment surface (Smetacek et al., 1984). Our results are in good agreement with these previous studies in that integrated sulfate reduction and $\mathrm{N}_{2}$ fixation rates, in general, were higher in summer and autumn months than in winter months (Fig. 7). Additionally, integrated sulfate reduction and $\mathrm{N}_{2}$ fixation rates slightly decreased in September $\left(794.9 \pm 109.5 \mathrm{nmol} \mathrm{SO}_{4}^{2-} \mathrm{cm}^{-2} \mathrm{~d}^{-1}\right.$ and $13.1 \pm 1.1 \mathrm{nmol} \mathrm{N} \mathrm{cm}^{-2} \mathrm{~d}^{-1}$, respectively) when compared to August $\left(883.2 \pm 146.8 \mathrm{nmol} \mathrm{SO}_{4}^{2-} \mathrm{cm}^{-2} \mathrm{~d}^{-1}\right.$ and $22.1 \pm 0.5 \mathrm{nmol} \mathrm{N} \mathrm{cm}^{-2} \mathrm{~d}^{-1}, \quad$ respectively), and then increased again in October $(1301.2 \pm 146.3 \mathrm{nmol}$ $\mathrm{SO}_{4}^{2-} \mathrm{cm}^{-2} \mathrm{~d}^{-1}$ and $21.9 \pm 0.5 \mathrm{nmol} \mathrm{N} \mathrm{cm}^{-2} \mathrm{~d}^{-1}$, respectively). This decrease in activity may be due to less-pronounced phytoplankton blooms in August, which would provide less material to the sediment (settling time of planktonic material to the seafloor during this stratification time is on the order of weeks; Graf et al., 1983) and lead to decreased September benthic activities.

For winter months, one hypothesis for the high sulfate reduction rates seen in Eckernförde Bay sediments during this time (Fig. 4) is that microbial "hot spots" of activity may form around localized patches of increased organic matter. It has been speculated that winter storms may lead to macrophyte erosion and cause macrophyte debris to reach the sediment (Meyer-Reil, 1983). Along with this debris, storms may deposit large quantities of sand and mud, sometimes several centimeters thick, on the sediment surface (Khandriche et al., 1986; Milkert, 1994; Orsi et al., 1996a), which could assist in the rapid burial of macrophyte and other surficial organic material. Treude et al. (2005), using chlorophyll $a$ concentrations and chlorin indexes, found that in early September, fresh organic material was located mostly at the sediment surface while in the winter, fresh organic matter appeared to be buried deeper into the sediment, producing irregular profiles in the top $10 \mathrm{~cm}$ of the sediment. The burial of macrophyte debris and patches of other surficial organic material could provide a highly localized concentration of organic matter that supports increased benthic microbial processes, forming a microbial "hot spot" of activity, such as was seen with sulfate reduction in November and February (Fig. 4). This type of microenvironment activity has been well documented in other coastal benthic habitats (e.g. Brandes and Devol, 1995; Bertics and Ziebis, 2010). Other sources of localized organic matter may include dead fauna (e.g. worms, fish, etc.), macrofaunal fecal pellets, and for February, the onset of bioturbation, which will be discussed more in Sect. 4.2.4. Because two sulfate reduction sub-cores came from one MUC core, it is understandable that in both cases, only two of the replicates showed co-occurring peaks in activity. It is possible that the other sulfate reduction MUC core, as well as the MUC core used for NA subsampling and the MUC cores from December, did not hit these patches of increased organic matter and thus did not show elevated microbial rates.

\subsubsection{Oxygen concentrations}

During times of stratification in Eckernförde Bay, organic matter from phytoplankton blooms reaches the deeper waters and microbial degradation of this material leads to the rapid 
consumption of oxygen. Eventually, hypoxic, or periodically anoxic, deeper waters can form and have been increasingly doing so in Eckernförde Bay over the last $25 \mathrm{yr}$ (Bange et al., 2011). In autumn, typically in October, strong easterly winds break up this stratification and the oxygen-depleted waters are replaced (Orsi et al., 1996b). A similar pattern was clearly seen during this study, in that the formation of hypoxic bottom waters began in June/July and continued through October, after which there was a break up of the stratification and a strong increase in bottom water oxygen concentrations in November (Figs. 1 and 7). Because oxygen is an inhibitor of the nitrogenase protein (Postgate, 1998) and because some sulfate-reducing activities can be suppressed by oxygen (reviewed in Muyzer and Stams, 2008), it is possible for these microbial activities to increase with decreasing oxygen concentrations. In general, integrated sulfate reduction and $\mathrm{N}_{2}$ fixation rates in Eckernförde Bay were higher when bottom water oxygen concentrations were lower (Fig. 7). However, relatively high integrated rates were still seen in November, despite the presence of $\sim 220 \mu \mathrm{M}$ oxygen concentrations. Two possible explanations for this high activity are (1) because oxygen is a highly favorable electron acceptor in relatively low concentrations compared to such as sulfate, penetration by diffusion into coastal sediments is only a few millimeters (Revsbech et al., 1980; Gunderson and Jørgensen, 1990) and was previously shown to penetrate only $2 \mathrm{~mm}$ into Eckernförde Bay sediments (Preisler et al., 2007), meaning that only the benthic microbial community in the top sediment layer is most likely affected by bottom water oxygen concentrations, and (2) many SRB have developed strategies for overcoming oxygen stress (e.g. Krekeler et al., 1997), with some SRB, of which Desulfovibrio vulgaris is one (Cypionka, 2000), even capable of respiring oxygen (e.g. Dilling and Cypionka, 1990). Overall, fluctuations in Eckernförde Bay water column oxygen concentrations probably serve as more of an indication of organic matter availability to the benthos (i.e. bacterial degradation of organic matter in the water column leads to consumption of oxygen, with the remaining organic matter settling on the seafloor), rather than directly influencing sulfate reduction and $\mathrm{N}_{2}$ fixation in the sediment. The exception may be for the surface microbial community $(0-1 \mathrm{~cm})$, which did indeed show highest microbial rates when bottom water oxygen concentrations were lowest (Figs. 1 and 3). However, hypoxia may have indirect impacts on the benthic microbial community through its influences on the benthic macrofauna community, which will be discussed in Sect. 4.2.4 of this discussion.

\subsubsection{Benthic organisms and bioturbation}

In late spring, the benthic community, mostly consisting of polychaetes (e.g. Pectinaria koreni, Nephtys ciliata, Polydora sp. and Capitella capitata), throughout the Kiel Bight begins to develop (Graf et al., 1982; Meyer-Reil, 1983). These organisms not only add to the organic matter con- tent of the sediment via biomass (Meyer-Reil, 1983), but also via bioturbation (as was recently redefined by Kristensen et al., 2012), i.e. all transport processes carried out by animals that directly or indirectly affect sediment matrices, including both particle reworking and burrow ventilation. Bioturbating organisms can increase benthic organic matter availability, and thereby increase microbial activities, through burrow construction (Aller and Aller, 1986; de Vaugelas and Buscail, 1990), through release of fecal pellets (Jørgensen, 1977b), through irrigation techniques that bring organic particles from the overlying water into the burrowsystem (Bertics and Ziebis, 2010), and through rapid subduction of labile organic matter that settles on the sediment surface (Graf, 1989; Jørgensen, 1996; Witte et al., 2003; reviewed in Meysman et al., 2006). The increase in organic matter associated with bioturbation has been shown to lead to the formation of reduced microniches within the sediment that can display increased sulfate reduction rates (Goldhaber et al., 1977; Bertics and Ziebis, 2010) and $\mathrm{N}_{2}$ fixation rates (Bertics et al., 2012) as well as increased rates of $\mathrm{N}_{2}$ fixation coupled to sulfate reduction (Bertics et al., 2010).

Bioirrigation results (Fig. 2; Dale et al., 2013) indicated that bioirrigation was present in early spring, and continued through the summer. As bottom water oxygen concentrations began to decrease (Fig. 7), bioirrigation decreased and eventually reached immeasurable levels in September, presumably because there was not enough oxygen present for the organisms to survive. Between April and August large specimens of errant polychaetes (presumably Nephtys ciliata) were frequently detected during core slicing (personal observations). The occurrence of these organisms may have led to the increased rates of sulfate reduction and $\mathrm{N}_{2}$ fixation seen in the upper half of the sediment cores during this time through the formation of sulfate-reducing microniches (Fig. 3; Bertics et al., 2010). In September, only dead polychaetes were seen on the sediment surface of collected cores (personal observations), which is in agreement with the documentation of a decline in bioturbation activity (Fig. 2; Dale et al., 2013). These dead worms may have provided a substantial organic carbon load to the surface sediments, which could be responsible for the intense sulfate reduction and NA seen in the top sediment layers in October (Fig. 3).

Aside from macrofaunal bioirrigation, sediments can also be irrigated via bubble movement through the sediment matrix (Roden and Tuttle, 1992; Haeckel et al., 2007). As bubbles rise through soft sediments, porewaters are mixed, causing solute fluxes, and possibly microbial activities, in the sediment to be enhanced (Haeckel et al., 2007). Porewater profiles in Eckernförde Bay sediments suggest that bubble formation and irrigation may have taken place over the course of this study (Dale et al., 2013). Those months that indicated the strongest presence of bubble irrigation were May, September and October (Dale et al., 2013). During these same months, porewater ammonium concentrations did not show the typical increase with sediment depth, but instead 
Table 1. Integrated $\mathrm{N}_{2}$ fixation rates in Eckernförde Bay sediments compared to rates from other benthic environments. Only the highest and lowest integrated values from Eckernförde Bay are shown. AR indicates acetylene reduction.

\begin{tabular}{|c|c|c|c|c|}
\hline Environment & $\begin{array}{r}\mathrm{N}_{2} \text { fixation } \\
\left(\mathrm{mmol} \mathrm{N} \mathrm{m} \mathrm{m}^{-2} \mathrm{~d}^{-1}\right)\end{array}$ & $\begin{array}{r}\text { Sediment Depth } \\
(\mathrm{cm})\end{array}$ & Method & Reference \\
\hline \multicolumn{5}{|l|}{ Eckernförde Bay } \\
\hline February 2011 (lowest) & $0.08 \pm 0.004$ & $0-18$ & $\mathrm{AR}$ & this study \\
\hline August 2010 (highest) & $0.22 \pm 0.005$ & $0-18$ & AR & this study \\
\hline \multicolumn{5}{|l|}{ Recent Studies } \\
\hline Eutrophic estuary & $0-18.5$ & $0-20$ & $\begin{array}{l}\text { Net } \mathrm{N}_{2} \text { fluxes in benthic } \\
\text { flux chambers and MIMS }\end{array}$ & Rao and Charette (2012) \\
\hline Bioturbated coastal lagoon & $0.8-8.05$ & $0-10$ & AR & Bertics et al. (2010) \\
\hline Lagoon microbial mat & 1.17 & mat & AR & Charpy et al. (2007) \\
\hline Mangrove sediments & $0-1.21$ & $0-1$ & AR & Lee and Joye (2006) \\
\hline Intertidal microbial mat & $1.63 \pm 1.15$ & mat & AR & Steppe and Paerl (2005) \\
\hline \multicolumn{5}{|c|}{ Traditional Averages by Benthic Environment } \\
\hline Heterotrophic & $0.02 \pm 0.03$ & - & - & Howarth et al. (1988) \\
\hline Phototrophic & $0.03 \pm 0.02$ & - & - & Howarth et al. (1988) \\
\hline Atlantic Ocean $(2800 \mathrm{~m})$ & 0.00008 & - & - & Howarth et al. (1988) \\
\hline$<200 \mathrm{~m}$ sediments & $0.02 \pm 0.01$ & - & - & Capone (1983) \\
\hline Bare estuarine sediments & $0.08 \pm 0.03$ & - & - & Capone (1983) \\
\hline Zostera estuarine sediments & 0.39 & - & - & Capone (1983) \\
\hline Coral reef sediments & $6.09 \pm 5.62$ & - & - & Capone (1983) \\
\hline Mangrove rhizosphere & 0.56 & - & - & Capone (1983) \\
\hline Mangrove mats & 1.66 & - & - & Capone (1983) \\
\hline Salt marsh rhizosphere & $5.27 \pm 3.64$ & - & - & Capone (1983) \\
\hline Salt marsh surface sediment & $0.38 \pm 0.41$ & - & - & Capone (1983) \\
\hline
\end{tabular}

remained relatively uniform (Fig. 3), perhaps due to bubble porewater mixing. It is therefore possible that these decreases in ammonium concentrations could have led to the increased NA seen at deeper sediment depths during these times (Fig. 3).

\subsection{Impact on benthic $\mathrm{N}$ cycling}

Comparing integrated rates of $\mathrm{N}_{2}$ fixation in Eckernförde Bay with rates from other studies/environments (Table 1), Eckernförde Bay rates most closely resemble those from bare estuarine sediments, salt marsh surface sediments, or those sediments present at water depths < $200 \mathrm{~m}$ (Capone, 1983). Most likely because there was cyanobacterial mat present at the surface of the Eckernförde Bay sediment cores, extremely high rates of $\mathrm{N}_{2}$ fixation were not measured. However, a more suitable question would concern how rates of $\mathrm{N}_{2}$ fixation rates compare with rates of $\mathrm{N}$ loss within this system. Previous modeling of Eckernförde Bay N-cycling estimated that sediments from this location have a fixed $\mathrm{N}$ loss rate of $0.08 \mathrm{mmol} \mathrm{N} \mathrm{m}^{-2} \mathrm{~d}^{-1}$ during the winter, i.e. in February (Dale et al., 2011). Comparing this rate estimate with the integrated rate of $\mathrm{N}_{2}$ fixation from February during this study (Fig. 10, Table 1), it appears as though $\mathrm{N}$ losses and $\mathrm{N}$ gains would be roughly equal, having a ra- tio of $\sim 1.1$. However, it is uncertain how rates of fixed $N$ loss vary over the course of the year, especially considering the high seasonal variability of environmental conditions and other microbial processes at this location. Instead, it is most likely that there exists high temporal variability in net $\mathrm{N}$ cycling in Eckernförde Bay sediments, similar to that seen in other marine sediments (e.g. Joye and Paerl, 1994). To date, there are no published studies directly measuring $\mathrm{N}$ turnover rates in Eckernförde Bay sediments, as also noted by Dale et al. (2011), making it impossible to produce an $\mathrm{N}$ budget for this system. Additionally, rates of $\mathrm{N}$ losses from around the Baltic Sea are highly variable and typically impacted by fluctuating hypoxia and macrofaunal presence (Karlson et al., 2005; Hietanen and Lukkari, 2007; Conley et al., 2009), and so a possibly inaccurate view of Eckernförde Bay benthic $\mathrm{N}$ cycling could be formed if comparing $\mathrm{N}_{2}$ fixation rates from this study with $\mathrm{N}$ losses from other studies around the Baltic Sea. In an attempt to provide some level of context, a study by Deutsch et al. (2010) found benthic denitrification rates from the southern and central Baltic Sea to range between 0.01 to $0.7 \mathrm{mmol} \mathrm{N} \mathrm{m}^{-2} \mathrm{~d}^{-1}$, which would indicate that the $\mathrm{N}_{2}$ fixation rates presented here could account for somewhere between $10-100 \%$ of the $\mathrm{N}$ lost via denitrification, depending on which numbers are used for comparison. Again, direct measurements of $\mathrm{N}$ losses in Eckernförde Bay 
sediments are necessary and would prove highly valuable for determination of $\mathrm{N}$ budgets within this system.

\section{Conclusions}

This study examined the possibility of benthic $\mathrm{N}_{2}$ fixation, perhaps coupled to sulfate reduction, occurring within the seasonally hypoxic Eckernförde Bay. Presented here is one of only a few studies looking at both of these microbial processes over the course of a year on almost a monthly basis. NA and sulfate reduction profiles showed similar patterns both spatially and temporally, suggesting that these two processes might be linked within Eckernförde Bay sediments. Molecular analysis confirmed the presence of nifH sequences related to two known $\mathrm{N}_{2}$ fixing SRB, Desulfovibrio vulgaris and Desulfonema limicola, further supporting the hypothesis that some of the observed NA may be coupled to sulfate reduction. Overall, these benthic processes appeared to be greatly impacted by many seasonally varying environmental conditions, such as temperature, planktonic blooms, oxygen, bioturbation, and storm events.

Areas of coastal marine hypoxia are globally increasing (Middelburg and Levin, 2009) and understanding N cycling in these environments is crucial for predicting how these expanding regions will impact $\mathrm{N}$ cycling worldwide. For this reason, areas such as Eckernförde Bay, which are seasonally hypoxic, are valuable study sites for monitoring the response of ecosystems to the changes in available organic matter and oxygen concentrations, stressing the importance of time series measurements in these coastal environments.

Acknowledgements. We would like to thank the captains and the crews of the R/V Alkor, RC Littorina, and RB Polarfuchs, as well as the onshore staff of the GEOMAR Technology and Logistics Center, for all of their assistance in monthly field sampling. We also thank the GEOMAR porewater geochemistry group, especially Bettina Domeyer, Anke Bleyer, and Regina Suhrberg, for geochemical analyses. Additional thanks goes to the members of the Treude and Schmitz working groups, especially Julia Hommer, Julia Frakas, Manuela Teupe, and Nicole Pinnow, for their laboratory assistance and to Stefan Sommer for scientific discussions. This is a publication of the "The Future Ocean" Cluster of Excellence funded by the German Research Foundation (DFG). Additional support was through the Alexander von Humboldt Foundation (A. v. H. Postdoctoral Fellowship to V. J. B) and provided from EU project HYPOX (EC Grant 226213, www.hypox.net). C. R. L. was financially supported by the DFG Sonderforschungsbereich 754 (www.sfb754.de).

Edited by: S. W. A. Naqvi

\section{References}

Aller, J. Y. and Aller, R. C.: Evidence for localized enhancement of biological activity associated with tube and burrow structures in deep-sea sediments at the HEBBLE site, western North Atlantic, Deep-Sea Res., 33, 755-790, 1986.
Anderson, J. J. and Devol, A. H.: Extent and intensity of the anoxic zone in basins and fjords, Deep-Sea Res., 34, 927-944, 1987.

Balzer, W., Erlenkeuser, H., Hartmann, M., Müller, P. J., and Pollehne, F.: Diagenesis and exchange processes at the benthic boundary, in: Seawater-Sediment Interactions in Coastal Waters, edited by: Rumohr, J., Walger, E., and Zeitzschel, B., SpringerVerlag, Berlin, 111-161, 1987.

Bange, H. W., Naqvi, S. W. A., and Codispoti, L. A.: The nitrogen cycle in the Arabian Sea, Prog. Oceanogr., 65, 145-158, 2005.

Bange, H. W., Hansen, H. P., Malien, F., Laß, K., Dale, A., Karstensen, J., Petereit, C., and Friedrichs, G.: Boknis Eck Time Series Station (SW Baltic Sea): Measurements from 1957 to 2010, LOICZ, Imprint 2011/1, 16-22, 2011.

Bertics, V. J. and Ziebis, W.: Bioturbation and the role of microniches for sulfate reduction in coastal marine sediments, Environ. Microbiol., 12, 3022-3034, 2010.

Bertics, V. J., Sohm, J. A., Treude, T., Chow, C. E. T., Capone, D. G., Fuhrman, J. A., and Ziebis, W.: Burrowing deeper into benthic nitrogen cycling: The impact of bioturbation on nitrogen fixation coupled to sulfate reduction, Mar. Ecol.-Prog. Ser., 409, 1-15, 2010.

Bertics, V. J., Sohm, J. A., Magnabosco, C., and Ziebis, W.: Denitrification and Nitrogen Fixation Dynamics Surrounding an Individual Ghost Shrimp (Neotrypaea californiensis) Burrow System, Appl. Environ. Microb.., 78, 3864-3872, 2012.

Brandes, J. A. and Devol, A. H.: Simultaneous nitrate and oxygen respiration in coastal sediments: Evidence for discrete diagenesis, J. Mar. Res., 53, 771-797, 1995.

Brandes, J. A. and Devol, A. H.: A global marine-fixed nitrogen isotopic budget: Implications for Holocene nitrogen cycling, Global Biogeochem. Cy., 16, 1120, doi:10.1029/2001GB001856, 2002.

Canfield, D. E.: Sulfate reduction and oxic respiration in marine sediments: implications for organic carbon preservations in euxinic environments, Deep-Sea Res., 36, 121-138, 1989.

Capone, D. G.: Benthic nitrogen fixation, in: Nitrogen in the Marine Environment, edited by: Carpenter, E. J. and Capone, D. G., John Wiley \& Sons Ltd, New York, 85-123, 1983.

Capone, D. G.: Benthic nitrogen fixation, in: Nitrogen Cycling in Coastal Marine Environments, Springer, edited by: Blackburn, T. H. and Sørensen, J., New York, 105-137, 1988.

Capone, D. G.: Determination of nitrogenase activity in aquatic samples using the acetylene reduction procedure, in: Handbook of Methods in Aquatic Microbial Ecology, edited by: Kemp, P. F., Sherr, B. F., Sherr, E. B., and Coles, J. J., CRC Press LLC, Boca Raton, 621-631, 1993.

Capone, D. G. and Knapp, A. N.: A marine nitrogen cycle fix?, Nature, 445, 159-160, 2007.

Capone, D. G., Burns, J. A., Michaels, A. F., Montoya, J. P., Subramaniam, A., and Carpenter, E. J.: Nitrogen fixation by Trichodesmium spp.: an important source of new nitrogen to the tropical and subtropical North Atlantic Ocean, Global Biogeochem. Cy., 19, GB2024, doi:10.1029/2004GB002331, 2005.

Carpenter, E. J. and Capone, D. G.: Nitrogen fixation in the marine environment, in: Nitrogen in the marine environment, edited by: Capone, D. G., Bronk, D. A., Mulholland, M. R., and Carpenter, E. J., Academic Press, Elsevier, San Diego, 141-198, 2008.

Charpy, L., Alliod, R., Rodier, M., and Golubic, S.: Benthic nitrogen fixation in the SW New Caledonia lagoon, Aquat. Microb. Ecol., 47, 73-81, 2007. 
Codispoti, L. A.: An oceanic fixed nitrogen sink exceeding $400 \mathrm{Tg} \mathrm{N} \mathrm{a}^{-1}$ vs the concept of homeostasis in the fixed-nitrogen inventory, Biogeosciences, 4, 233-253, doi:10.5194/bg-4-2332007, 2007.

Codispoti, L. A., Brandes, J., Christensen, J., Devol, A., Naqvi, S., Paerl, H., and Yoshinari, T.: The oceanic fixed nitrogen and nitrous oxide budgets: Moving targets as we enter the anthropocene?, Sci. Mar., 65, Supplement 2, 85-105, 2001.

Conley, D. J., Björck, S., Bonsdorff, E., Carstensen, J., Destouni, G., Gustafsson, B. G., Hietanen, S., Kortekaas, M., Kuosa, H., Meier, H. E. M., Müller-Karulis, B., Nordberg, K., Norkko, A., Nürnberg, G., Pitkänen, H., Rabalais, N. N., Rosenberg, R., Savchuk, O. P., Slomp, C. P., Voss, M., Wulff, F., and Zillën, L.: Hypoxia-related processes in the Baltic Sea, Environ. Sci. Technol., 43, 3412-3420, 2009.

Cypionka, H.: Oxygen respiration by Desulfovibrio species, Annu. Rev. Microbiol., 54, 827-848, 2000.

Dale, A. W., Sommer, S., Bohlen, L., Treude, T., Bertics, V. J., Bange, H. W., Pfannkuche, O., Schorp, T., Mattsdotter, M., and Wallmann, K.: Rates and regulation of nitrogen cycling in seasonally hypoxic sediments during winter (Boknis Eck, SW Baltic Sea): Sensitivity to environmental variables, Estuar. Coast. Shelf S., 95, 14-28, 2011.

Dale, A. W., Bertics, V. J., Treude, T., Sommer, S., and Wallmann, K.: Modeling benthic-pelagic nutrient exchange processes and porewater distributions in a seasonally hypoxic sediment: evidence for massive phosphate release by Beggiatoa?, Biogeosciences, 10, 629-651, doi:10.5194/bg-10-629-2013, 2013.

Dalsgaard, T., Thamdrup, B., and Canfield, D. E.: Anaerobic ammonium oxidation (anammox) in the marine environment, Res. Microbiol., 156, 457-464, 2005.

Deutsch, C., Sigman, D. M., Thunell, R. C., Meckler, A. N., and Haug, G. H.: Isotopic constraints on glacial/interglacial changes in the oceanic nitrogen budget, Global Biogeochem. Cy., 18, GB4012, doi:10.1029/2003GB002189, 2004.

Deutsch, B., Forster, S., Wilhelm, M., Dippner, J. W., and Voss, M.: Denitrification in sediments as a major nitrogen sink in the Baltic Sea: an extrapolation using sediment characteristics, Biogeosciences, 7, 3259-3271, doi:10.5194/bg-7-3259-2010, 2010.

de Vaugelas, J. and Buscail, R.: Organic matter distribution in burrows of the thalassinid crustacean Callichirus laurae, Gulf of Aqaba (Red Sea), Hydrobiologia, 207, 269-277, 1990.

Dicker, H. J. and Smith, D. W.: Enumeration and relative importance of acetylene-reducing (nitrogen-fixing) bacteria in a Delaware salt marsh, Appl. Environ. Microb., 39, 1019-1025, 1980.

Dilling, W. and Cypionka, H.: Aerobic respiration in sulphatereducing bacteria, Arch. Microbiol., 71, 123-128, 1990.

Dixon, R. A.: The genetic complexity of nitrogen fixation, J. Gen. Microbiol., 130, 2745-2755, 1984.

Fossing, H. and Jørgensen, B. B.: Measurements of bacterial sulphate reduction in sediments: evaluation of a single-step chromium reduction method, Biogeochemistry, 8, 205-222, 1989.

Fukui, M., Teske, A., Aßmus, B., Muyzer, G., and Widdel, F.: Physiology, phylogenetic relationships, and ecology of filamentous sulfate-reducing bacteria (genus Desulfonema), Arch. Microbiol., 172, 193-203, 1999.
Fulweiler, R. W., Nixon, S. W., Buckley, B. A., and Granger, S. L.: Reversal of the net dinitrogen gas flux in coastal marine sediments, Nature, 448, 180-182, 2007.

Graf, G.: Benthic-pelagic coupling in a deep-sea community, Nature, 341, 437-439, 1989.

Graf, G., Bengtsson, W., Diesner, U., Schulz, R., and Theede, H.: Benthic response to sedimentation of a spring phytoplankton bloom: Process and budget, Mar. Biol., 67, 201-208, 1982.

Graf, G., Schulz, R., Peinert, R., and Meyer-Reil, L.-A.: Benthic response to sedimentation events during autumn to spring at a shallow water station in the Western Kiel Bight I. Analysis of processes on a community level, Mar. Biol., 77, 235-246, 1983.

Grasshoff, K., Ehrhardt, M., and Kremmling, K.: Methods of seawater analysis, Verlag Chemie, Weinheim, 1999.

Großkopf, T., Mohr, W., Baustian, T., Schunck, H., Gill, D., Kuypers, M. M. M., Lavik, G., Schmitz, R. A., Wallace, D. W. R., and LaRoche, J.: Doubling of marine dinitrogen-fixation rates based on direct measurements, Nature, 488, 361-364, 2012.

Goldhaber, M. B., Aller, R. C., Cochran, J. K., Rosenfeld, J. K., Martens, C. S., and Berner, R. A.: Sulfate reduction, diffusion, and bioturbation in Long Island Sound sediments: report of the FOAM group, Am. J. Sci., 277, 193-237, 1977.

Gunderson, J. K. and Jørgensen, B. B.: Microstructure of diffusive boundary layers and the oxygen uptake of the sea floor, Nature, 345, 604-607, 1990.

Haeckel, M., Boudreau, B. P., and Wallmann, K.: Bubble-induced porewater mixing: a 3-D model for deep porewater irrigation, Geochim. Cosmochim. Ac., 71, 5135-5154, 2007.

Hamersley, M. R., Lavik, G., Woebken, D., Rattray, J. E., Lam, P., Hopmans, E. C., Sinninghe Damsté, J. S., Krüge, S., Graco, M., Gutiérrez, D., and Kuypers, M. M. M.: Anaerobic ammonium oxidation in the Peruvian oxygen minimum zone, Limnol Oceanogr., 52, 923-933, 2007.

Hansen, H. P., Giesenhagen, H. C., and Behrends, G.: Seasonal and long-term control of bottom-water oxygen deficiency in a stratified shallow-water coastal system, ICES J. Mar. Sci., 56, 65-71, 1999.

Heidelberg, J. F., Seshadri, R., Haveman, S. A., Hemme, C. L., Paulsen, I. T., Kolonay, J. F., Eisen, J. A., Ward, N., Methe, B., Brinkac, L. M., Daugherty, S. C., Deboy, R. T., Dodson, R. J., Durkin, A. S., Madupu, R., Nelson, W. C., Sullivan, S. A., Fouts, D., Haft, D. H., Selengut, J., Peterson, J. D., Davidsen, T. M., Zafar, N., Zhou, L., Radune, D., Dimitrov, G., Hance, M., Tran, K., Khouri, H., Gill, J., Utterback, T. R., Feldblyum, T. V., Wall, J. D., Voordouw, G., and Fraser, C. M.: The genome sequence of the anaerobic, sulfate-reducing bacterium Desulfovibrio vulgaris Hildenborough, Nat. Biotechnol., 22, 554-559, 2004.

Helly, J. J. and Levin, L. A.: Global distribution of naturally occurring marine hypoxia on continental margins, Deep-Sea Res. Pt. I, 51, 1159-1168, 2004.

Herbert, R. A.: Heterotrophic nitrogen fixation in shallow estuarine sediments, J. Exp. Mar. Biol. Ecol., 18, 215-225, 1975.

Hietanen, S. and Lukkari, K.: Effects of short-term anoxia on benthic denitrification, nutrient fluxes, and phosphorus forms in the sediment, Aquat. Microb. Ecol., 49, 293-302, 2007.

Howarth, R. W., Marino, R., Lane, J., and Cole, J. J.: Nitrogen fixation in freshwater, estuarine, and marine ecosystems: 1 . Rates and importance, Limnol. Oceanogr., 33, 669-687, 1988. 
Hulth, S., Aller, R. C., Canfield, D. E., Dalsgaard, T., Engström, P., Gilbert, F., Sundbäck, K., and Thamdrup, B.: Nitrogen removal in marine environments: recent findings and future research challenges, Mar. Chem., 94, 125-145, 2005.

Jørgensen, B. B.: The sulfur cycle of a coastal marine sediment (Limfjorden, Denmark), Limnol. Oceanogr., 22, 814-832, 1977a.

Jørgensen, B. B.: Bacterial sulfate reduction within reduced microniches of oxidized marine sediments, Mar. Biol., 41, 7-17, 1977b.

Jørgensen, B. B.: A comparison of methods for the quantification of bacterial sulphate reduction in coastal marine sediments: I. Measurements with radiotracer techniques, Geomicrobiol. J., 1, 11-27, 1978.

Jørgensen, B. B.: Mineralization of organic matter in the sea bed: the role of sulphate reduction, Nature, 296, 643-645, 1982.

Jørgensen, B. B.: Material flux in the sediment, in: Eutrophication in coastal marine ecosystems, edited by: Jørgensen, B. B. and Richardson, K., American Geophysical Union, Washington DC, 115-135, 1996.

Joshi, H. M. and Tabita, F. R.: A global two component signal transduction system that integrates the control of photosynthesis, carbon dioxide assimilation, and nitrogen fixation, P. Natl. Acad. Sci. USA, 93, 14515-14520, 1996.

Joye, S. B. and Paerl, H. W.: Nitrogen cycling in microbial mats: rates and patterns of denitrification and nitrogen fixation, Mar. Biol., 119, 285-295, 1994.

Kallmeyer, J., Ferdelman, T. G., Weber, A., Fossing, H., and Jørgensen, B. B.: A cold chromium distillation procedure for radiolabeled sulfide applied to sulphate reduction measurements, Limnol. Oceanogr.-Meth., 2, 171-180, 2004.

Kamykowski, D. and Zentara, S. J.: Hypoxia in the world ocean as recorded in the historical data set. Deep-Sea Res. Pt. I, 37, 1861$1874,1990$.

Karlson, K., Hulth, S., Ringdahl, K., and Rosenberg, R.: Experimental recolonization of Baltic Sea reduced sediments: survival of benthic macrofauna and effects on nutrient cycling, Mar. Ecol.-Prog. Ser., 294, 35-49, 2005.

Kartal, B., Kuypers, M. M. M., Lavik, G., Schalk, J., Op den Camp, H. J. M., Jetten, M. S. M., and Strous, M.: Anammox bacteria disguised as denitrifiers: nitrate reduction to dinitrogen gas via nitrite and ammonium, Environ. Microbiol., 9, 635-642, 2007.

Khandriche, A., Werner, F., and Erlenkeuser, H.: Auswirkungen der Oststürme vom Winter 1978/79 auf die Sedimentation im Schlickbereich der Eckernförder Bucht (Westliche Ostsee), Meyniana, 38, 125-151, 1986.

Knapp, A. N.: The sensitivity of marine $\mathrm{N}_{2}$ fixation to dissolved inorganic nitrogen, Front. Microbiol., 3, 374, doi:10.3389/fmicb.2012.00374, 2012.

Krekeler, D., Teske, A., and Cypionka, H.: Strategies of sulfatereducing bacteria to escape oxygen stress in a cyanobacterial mat, FEMS Microbiol. Ecol., 25, 89-96, 1997.

Kristensen, E., Penha-Lopes, G., Delefosse, M., Valdemarsen, T., Quintana, C. O., and Banta, G. T.: What is bioturbation? The need for a precise definition for fauna in aquatic sciences, Mar. Ecol.-Prog. Ser., 446, 285-302, 2012.

Kuypers, M. M. M., Lavik, G., Woebken, D., Schmid, M., Fuchs, B. M., Amann, R., Jørgensen, B. B., and Jetten, M. S. M.: Massive nitrogen loss from the Benguela upwelling system through anaerobic ammonium oxidation, P. Natl. Acad. Sci. USA, 102, 6478-6483, 2005.

Lee, R. Y. and Joye, S. B.: Seasonal patterns of nitrogen fixation and denitrification in oceanic mangrove habitats, Mar. Ecol.-Prog. Ser., 307, 127-141, 2006.

Le Gall, J., Senez, J. C., and Pichinoty, F.: Fixation de l'azote par les bactéries sulfato-réductrices: isolement et caracterisation de souches actives, Annls. Inst. Pasteur, 96, 223-230, 1959.

Levin, L. A.: Oxygen minimum zone benthos: Adaptations and community response to hypoxia, Oceanogr. Mar. Biol., 41, 1-45, 2003.

Ludwig, W., Strunk, O., Westram, R., Richter, L., Meier, H., Yadhukumar, Buchner, A., Lai, T., Steppi, S., Jobb, G., Förster, W. Brettske, I., Gerber, S., Ginhart, A. W., Gross, O., Grumann, S., Hermann, S., Jost, R., König, A., Liss, T., Lüßmann, R., May, M., Nonhoff, B., Reichel, B., Strehlow, R., Stamatakis, A., Stuckmann, N., Vilbig, A., Lenke, M., Ludwig, T., Bode A., and Schleifer, K.: ARB: a software environment for sequence data, Nucleic Acids Res., 32, 1363-1371, 2004.

Madigan, M. T., Martinko, J. M., and Parker, J.: Brock: Biology of Microorganisms, Prentice Hall, New Jersey, 2003.

McGlathery, K. J., Risgaard-Petersen, N., Christensen, P. B.: Temporal and spatial variation in nitrogen fixation activity in the eelgrass Zostera marina rhizosphere, Mar. Ecol.-Prog. Ser., 168, 245-258, 1998.

Meyer-Reil, L.-A.: Benthic response to sedimentation events during autumn to spring at a shallow water station in the Western Kiel Bight II, Analysis of benthic bacterial populations, Mar. Biol., 77, 247-256, 1983.

Meysman, F. J. R., Middelburg, J. J., and Heip, C. H. R.: Bioturbation: a fresh look at Darwin's last idea, Trends Ecol. Evol., 21, 688-695, 2006.

Middelburg, J. J. and Levin, L. A.: Coastal hypoxia and sediment biogeochemistry, Biogeosciences, 6, 1273-1293, doi:10.5194/bg-6-1273-2009, 2009.

Middelburg, J. J., Calvert, S. E., and Karlin, R.: Organic-rich transitional facies in silled basins - Response to sea-level change, Geology, 19, 679-682, 1991.

Milkert, D.: Auswirkungen von Stürmen auf die Schlicksedimente der westlichen Ostsee (Influence of storms on muddy sediments in the western Baltic Sea), Berichte Geologisch-Paläontologisches Institut der Universität Kiel, 66, 153 pp., 1994.

Mohr, W., Großkopf, T., Wallace, D. W. R., and LaRoche, J.: Methodological underestimation of oceanic nitrogen fixation rates, PLoS ONE, 5, e12583, doi:10.1371/journal.pone.0012583, 2010.

Moisander, P. H., Zhang, R., Boyle, E. A., Hewson, I., Montoya, J. P., and Zehr, J. P.: Analogous nutrient limitations in unicellular diazotrophs and Prochlorococcus in the South Pacific Ocean, ISME J., 6 733-744, 2012.

Molina, V. and Farías, L.: Aerobic ammonium oxidation in the oxycline and oxygen minimum zone of the eastern South Pacific off northern Chile, Deep-Sea Res. Pt. II, 56, 1009-1018, 2009.

Muyzer, G. and Stams, A. J. M.: The ecology and biotechnology of sulphate-reducing bacteria, Nat. Rev. Microbiol., 6, 441-454, 2008.

Nedwell, D. B. and Aziz, S. A. A.: Heterotrophic nitrogen fixation in an intertidal saltmarsh sediment, Estuar. Coast. Mar. Sci., 10, 699-702, 1980. 
Nielsen, L. B., Finster, K., Welsh, D. T., Donelly, A., Herbert, R. A., de Wit, R., and Lomstein, B. A.: Sulphate reduction and nitrogen fixation rates associated with roots, rhizomes and sediments from Zostera noltii and Spartina maritima meadows, Environ. Microbiol., 3, 63-71, 2001.

O’Donohue, M. J., Moriarty, D. J. W., and MacRae, I. C.: Nitrogen fixation in sediments and the rhizosphere of the seagrass Zostera capricorni, Microb. Ecol., 22, 53-64, 1991.

Orcutt, K. M., Lipschultz, F., Gundersen, K., Arimoto, R., Michaels, A. F., Knap, A. H., and Gallon, J. R: A seasonal study of the significance of $\mathrm{N}_{2}$ fixation by Trichodesmium spp. at the Bermuda Atlantic Time-series Study (BATS) site, Deep-Sea Res. Part II, 48, 1583-1608, 2001.

Orsi, T. H., Anderson, A. L., and Lyons, A. P.: X-ray tomographic analysis of sediment macrostructure in Eckernförde Bay, western Baltic Sea, Geo-Mar. Lett., 16, 232-239, 1996a.

Orsi, T. H., Werner, F., Milkert, D., Anderson, A. L., and Bryant, W. R.: Environmental overview of Eckernförde Bay, northern Germany, Geo-Mar. Lett., 16, 140-147, 1996b.

Patriquin, D. G. and Knowles, R.: Nitrogen fixation in the rhizosphere of marine angiosperms, Mar. Biol., 16, 49-58, 1972.

Preisler, A., de Beer, D., Lichtschlag, A., Lavik, G., Boetius, A., and Jørgensen, B. B.: Biological and chemical sulfide oxidation in a Beggiatoa inhabited marine sediment, ISME J., 1, 341-353, 2007.

Postgate, J. R.: The fundamentals of nitrogen fixation, Cambridge University Press, London, 1982.

Postgate, J. R.: The Sulphate-Reducing Bacteria, 2nd Edn., 130, Cambridge University Press, London, 1984.

Postgate, J. R.: Nitrogen fixation, Cambridge University Press, London, 1998.

Postgate, J. R., Kent, H. M., Hill, S., and Blackburn H.: Nitrogen fixation by Desulfovibrio gigas and other species of Desulfovibrio, in: Nitrogen fixation and $\mathrm{CO}_{2}$ metabolism, edited by: Ludden, P. W. and Burris, J. E., Elsevier, Amsterdam, 225-234, 1985.

Rao, A. M. F. and Charette, M. A.: Benthic nitrogen fixation in an eutrophic estuary affected by ground water discharge, J. Coast. Res., 28, 477-485, 2012.

Revsbech, N. P., Jørgensen, B. B., and Blackburn, T. H.: Oxygen in the sea bottom measured with a microelectrode, Science, 207, 1355-1356, 1980.

Riederer-Henderson, M. A. and Wilson, P. W.: Nitrogen fixation by sulphate reducing bacteria, J. Gen. Microbiol., 61, 27-31, 1970.

Roden, E. E. and Tuttle, J. H.: Sulfide Release from Estuarine Sediments Underlying Anoxic Bottom Water, Limnol. Oceanogr., 37, 725-738, 1992.

Rosenberg, R., Nilsson, H. C., and Diaz, R. J.: Response of benthic fauna and changing sediment redox profiles over a hypoxic gradient, Estuar. Coast. Shelf Sci., 53, 343-350, 2001.

Rowe, G. T., Kaegi, M. E. C., Morse, J. W., Boland, G. S., and Briones E. G. E.: Sediment community metabolism associated with continental shelf hypoxia, Northern Gulf of Mexico, Estuaries, 25, 1097-1106, 2002.

Sisler, F. D. and Zobell, C. E.: Nitrogen fixation by sulphatereducing bacteria indicated by nitrogen/argon ratios, Science, 262, 209-210, 1951.

Smetacek, V., Bodungen, B. V., Knoppers, B., Peinert, R., Pollehne, F., Stegmann, P., and Zeitzschel, B.: Seasonal stages characterizing the annual cycle of an inshore pelagic system, Rapp. P.-v.
Reun. Cons. int. Explor. Mer., 183, 126-135, 1984.

Steppe, T. F. and Paerl, H. W.: Potential $\mathrm{N}_{2}$ fixation by sulphatereducing bacteria in a marine intertidal microbial mat, Aquat. Microb. Ecol., 28, 1-12, 2002.

Steppe, T. F. and Paerl, H. W.: Nitrogenase activity and nifH expression in a marine intertidal microbial mat, Microb. Ecol., 49, 315-324, 2005.

Stramma, L., Johnson, G. C., Sprintall, J., and Mohrholz, V.: Expanding Oxygen Minimum Zones in the Tropical Oceans, Science, 320, 655-658, 2008.

Thamdrup, B., Hansen, J. W., and Jørgensen, B. B.: Temperature dependence of aerobic respiration in a coastal sediment, FEMS Microbiol. Ecol., 25, 189-200, 1998.

Thamdrup, B., Dalsgaard, T., Jensen, M. M., Ulloa, O., Farías, L., and Escribano, R.: Anaerobic ammonium oxidation in the oxygen-deficient waters off northern Chile, Limnol. Oceanogr., 51, 2145-2156, 2006.

Tichi, M. A. and Tabita, F. R.: Maintenance and control of redox poise in Rhodobacter capsulatus strains deficient in the Calvin- Benson-Bassham pathway, Arch. Microbiol., 174, 322333, 2000.

Treude, T., Krüger, M., Boetius, A., and Jørgensen, B. B.: Environmental control on anaerobic oxidation of methane in the gassy sediments of Eckernförde Bay (German Baltic), Limnol. Oceanogr., 50, 1771-1786, 2005.

Thomas, W. H.: Surface nitrogenous nutrients and phytoplankton in the northeastern tropical Pacific ocean, Limnol. Oceanogr., 15, 393-400, 1966.

Turk, K. A. , Rees, A. P., Zehr, J. P., Pereira, N., Swift, P., Shelley, R., Lohan, M., Woodward, E. M. S., and Gilbert, J.: Nitrogen fixation and nitrogenase (nifH) expression in tropical waters of the eastern North Atlantic, ISME J., 5, 1201-1212, 2011.

Ulloa, O. and Pantoja, S.: The oxygen minimum zone of the eastern South Pacific, Deep-Sea Res. Pt. II, 56, 987-991, 2009.

Welsh, D. T., Bourguès, S., de Wit, R., and Herbert, R. A.: Seasonal variations in nitrogen-fixation (acetylene reduction) and sulphate-reduction rates in the rhizosphere of Zostera noltii: nitrogen fixation by sulphate-reducing bacteria, Mar. Biol., 125, 619-628, 1996.

Widdel, F.: Genus Desulfonema, in: Bergey's manual of systematic bacteriology, edited by: Staley, J. T., Bryant, M. P., Pfennig, N., and Holt, J. G., Williams \& Wilkins, Baltimore, 3, 2128-2131, 1989.

Witte, U., Aberle, N., Sand, M., and Wenzhöfer, F.: Rapid response of a deep-sea benthic community to POM enrichment: An in situ experimental study, Mar. Ecol.-Prog. Ser., 251, 27-36, 2003.

Wyrtki, K.: The oxygen minima in relation to ocean circulation, Deep-Sea Res., 9, 11-23, 1962.

Zehr, J. P. and Turner, P. J.: Nitrogen fixation: Nitrogenase genes and gene expression, in: Methods in Microbiology, edited by: Paul, J. H., Academic Press Inc., San Diego, 30, 271-286, 2001.

Zehr, J. P., Mellon, M., Braun, S., Litaker, W., Steppe, T., and Paerl, H. W.: Diversity of heterotrophic nitrogen fixation genes in a marine cyanobacterial mat, Appl. Environ. Microb., 61, 2527-2532, 1995.

Zehr, J. P., Mellon, M. T., and Zani, S.: New nitrogen-fixing microorganisms detected in oligotrophic oceans by amplification of nitrogenase (nifH) genes, Appl. Environ. Microb., 64, 50675067, 1998. 